\title{
Son 10 Yilda Kompozit Rezin Restorasyonlar: İn Vivo ve İn Vitro Çalışmalarla Bir Derleme
}

\section{Composite Resin Restorations in the Last 10 Years: A Review with In Vivo and In Vitro Studies Evaluation}

\author{
Nimet ÜNLÜ1 (D) \\ nunlu@selcuk.edu.tr
}

\author{
Sultan Gizem ÜLKÜ ${ }^{* 1}$ (D) \\ sltngzm@gmail.com
}

\begin{abstract}
öz
Kompozit rezinlerin 1962 yılında Bowen tarafından tanıtılmalarıyla bașlayan süreçte, hastaların estetik beklentisinin artması ve amalgam hakkındaki endișeler kompozit rezinleri tercih edilen materyal haline getirmiștir. Kompozit rezinlerin estetik olması, konservatif kavite preparasyonuna imkan sağlaması ve tamir edilebilmesi avantajlarının yanı sıra polimerizasyon büzülmesi, fonksiyonel tüberküllerde kullanımında aşınma direncinin az olması gibi dezavantajları bulunmaktadır. 1960'ların bașından günümüze kadar kompozit rezinler hakkında çeșitli araștırmalar yapılmıș, kompozit rezin materyali geliştirilmeye çalışılmıştır. Geliştirilen özellikler ve bu alanda yapılan araştırmalar ile kompozit rezinlerin dezavantajlarının elimine edilmesi hedeflenmiștir. Bununla birlikte literatürde kompozit rezin ile ilgili hem in vivo hem de in vitro araștırmalar ın sayısı da artmıștır . Literatürdeki in vivo araștırmalarda hastaların yașı, cinsiyeti ve incelenen toplam hasta sayısı gibi hastaya ait veriler yer almakla birlikte kullanılan materyaller, materyallerin klinik değerlendirme kriterlerine ait veriler, restorasyon ömrü gibi veriler de çalışmanın değerlendirilen verileri arasında yer almaktadır. Bu makalede, kompozit rezin restorasyonlar ve diğer restoratif materyaller ile ilgili literatürde yapılan 2010 ve sonrası in vivo ve in vitro çalışmalar derlenmiş ve bu çalışmalarda yer alan tüm veriler incelenerek tablolar halinde sunulmuştur.
\end{abstract}

Anahtar Kelimeler: Kompozit rezin restorasyonlar, Klinik araştırmalar, İn vivo ve in vitro araştırmalar

Geliș: 18.09 .2020

Kabul: 14.12 .2020

Yayın: 31.12.2020

\begin{abstract}
In the process that started with the introduction of composite resins by Bowen in 1962, the increased aesthetic expectation of patients and concerns about amalgam have made composite resins the preferred material. As well as the advantages that composite resins being aesthetic, allow for conservative cavity preparation and can be repaired, there are disadvantages such as polymerization shrinkage, low wear resistance in use in functional tubercles. Various researches have been conducted on composite resins since the early 1960s and a composite resin material has been developed. It is aimed to eliminate the disadvantages of composite resins with the developed properties and researches in this field. However, the number of both in vivo and in vitro studies on composite resin has increased in the literature. In vivo studies in the literature include patient data such as age, gender, and the total number of patients examined, and data such as the materials used, the data of the clinical evaluation criteria of the materials, and the restoration survival are among the evaluated data of the study. In this article, in vivo and in vitro studies conducted in the literature on composite resin restorations and other restorative materials in 2010 and later are compiled and all data in these studies are examined and presented in tables.
\end{abstract}

Keywords: Composite resin restorations, Clinical researches, In vivo and in vitro researches

Received: $18.09 .2020 \quad$ Accepted: $14.12 .2020 \quad$ Published: 31.12 .2020

Atıf / Citation: Ünlü N, Ülkü SG. Son 10 yılda kompozit rezin restorasyonlar: in vivo ve in vitro çalışmalarla bir derleme. NEU Dent J. 2020;2:124-45.

\footnotetext{
* Sorumlu Yazar / Corresponding Author

1. Selçuk Üniversitesi Diș Hekimliği Fakültesi Konya, Türkiye
}

"This article is licensed under a $\underline{\text { Creative }}$ Commons Attribution-NonCommercial 4.0 International License(CC BY-NC 4.0) 


\section{Gíriş}

Restoratif diş hekimliğinde diș dokularında çeşitli nedenlerle meydana gelen madde kaybının onarılması ile diș dokularının bütünlügünün korunup devamlılığının sağlanması, fonksiyon ve estetiğin yeniden oluşturulması amaçlanmaktadır. Bunları yaparken aynı zamanda kalan dokuların korunması önem arz eder.

$\mathrm{Bu}$ amaçla geliştirilen kompozit rezinler 70’lerin başlarından beri diş hekimliğinde kullanılmaktadır. Amalgamın biyouyumluluğu konusunda duyulan endişelerden dolayı, 90'lı yıllarda posterior dişlerde kullanımı artış göstermiştir. ${ }^{1,2}$ Kompozit rezinlerin estetik olması ve preparasyon esnasında diș yapısından daha az madde kaldırılmasına olanak sağlaması gibi nedenlerle günümüzde birçok ülkede restorasyon/restorasyon tamir vakalarında en çok tercih edilen restoratif materyal durumuna gelmiştir. $^{1}$ Kompozit; birbiri içinde çözünmeyen farklı yapı ve özellikteki iki veya daha fazla maddenin fiziksel karışımı anlamına gelmektedir. Diş hekimliğinde kullanılan kompozit rezinler, geleneksel olarak silikat cam partiküllerinin akrilik monomerler ile karışımı ve bu karışımın uygulama sonrasında polimerize olması ile oluşmaktadır.

Restoratif Diș Hekimliği'nde kompozit rezinlerin seçilip kullanılması, çeşitli niteliklerinin olmasını ve var olan içeriklerinin belli bir dengede bulunmasını gerektirir. Bu nitelikler; özellikle ön dişler için diş rengine uyumlu olmasiyken, çiğneme kuvvetlerine yeterli direnç gösterebilmesi de daha çok posterior dişler için tercih edilen niteliklerdir. Ayrıca ağız sıvıları ve gıdalardan etkilenip bozulmamalı, hacimsel değişikliğe uğrayarak aralık oluşumuna neden olmamalı, kavite duvarlarına adaptasyonu iyi olmalı, diş sert dokularına adezyonu yeterli olmalıdır. Aynı zamanda diş eti ve periodontal dokulara karşı irritan olmamalı, biyouyumlu olmalıdır. Ek olarak suya karşı geçirgen olmamalı, ısıyı iletmemeli ve ağız içerisindeki ısı değişikliklerinde diş sert dokularına benzer şekilde hacimsel değişiklik gösterebilmelidir. İdeal bir kompozit rezin materyal radyoopak ve yüksek polimerizasyon dönüşüm derecesi ile düşük polimerizasyon büzülme stres değerine sahip olmalıdır.

Kompozitlerin başlıca avantajlarını sıralayacak olursak; estetik özelliği, konservatif kavite preparasyonu, yalıtkan olması, düşük termal iletkenliği, universal kullanımı, diş yapısına bağlanarak iyi retansiyon sağlaması, düşük mikrosızıntı, minimum renklenme ve kalan diş dokusuna artmış destek sağlaması ile tamir edilebilir olmasıdır. Kompozit rezinlerin başlıca dezavantajı ise polimerizasyon büzülmesine bağlı restorasyon ve restoratif materyal arasında aralık oluşumudur. Yerleştirmesi, uygulaması amalgama kıyaslandığında zor ve zaman alıcıdır. Bitirme ve polisaj işlemleri, konturlama daha zordur. İzolasyon, asit, primer ve adeziv uygulanması teknik hassasiyet gerektirir. Yüksek okluzal stres alanlarında veya dișin okluzal kontaklarının tamamı kompozit olduğunda okluzal aşınma meydana gelir. Yüksek ısısal genleşme katsayısı vardır. C faktör ne kadar yüksekse polimerizasyon büzülmesinden etkilenme riski de o derece fazladır. Kompozit restorasyonlarda $C$ faktörün etkisinin azaltılması için; adeziv olarak dolduruculu bir bağlayıcı adeziv kullanılması, 0,5 mm kalınlığında akışkan kompozit ve stres kırıcı olarak Rezin Modifiye Cam İyonomer Siman (RMCIS) gibi bir kaide uygulanması ile kompozitin tabakalar halinde yerleştirilmesi önerilmiştir. Kompozit restorasyonların başarısı için; kavite derinleştikçe üniversal kurallar (rezistans ve retansiyon formları) uygulanabilir. Retansiyonu artırmak adına minenin pürüzlendirilmesi ve dentin bağlayıcı ajanların uygun şekilde kullanımı önerilir. Mikromekanik bağlantı ile rezistans formu sağlanabilir. Bu derlemede kompozit rezin restorasyonların klinik başarısında etkili olan bir çok faktör üzerine literatürde yer alan çalışmalar derlenerek bir değerlendirme yapılması amaçlanmıştır.

\section{Kompozit Rezin Restorasyonların Klinik Başarı- sında Etkili Olan Bazı Faktörler;}

Restorasyonu yapan kişinin deneyimi, kullanılan materyalin özellikleri, oral hijyen ve oral çevrede hastaya bağlı farklılıklar, restorasyonun yeri ve büyüklüğü gibi unsurlar restorasyonun ömrünü etkileyen unsurlardan bazlarıdır. Kompozit rezin restorasyonların klinik başarısında etkili olan diğer faktörler aşağıda detaylı bir şekilde yazılmıştır.

\section{- Hastayla İlgili Faktörler}

Hastanın sosyoekonomik durumu restorasyonun ağızda kalma süresinde önemli bir belirleyicidir. Sosyoekonomik durumu daha düşük olan hastalarda restorasyonun başarısız olma ihtimalinin daha yüksek olduğu rapor edilmiştir. ${ }^{3}$ Yüksek çürük riskine (YÇ) sahip kişilerde restorasyon başarısızlık riskinin daha fazla olduğ $\mathrm{u}^{4}$ gözlenmiștir. 6 yıllık prospektif randomize bir çalışmada Pallesen ve ark. ${ }^{5}$ tekrarlayan çürük lezyonlarının \%63'nün yüksek çürük risk grubunda olduğunu bildirmiştir. Literatürde restorasyon başarısını etkileyen major faktörlerin çürük riski ve bruksizm olduğunu bildiren çalışmalar mevcuttur. ${ }^{4,6,7}$

Ravasini ve ark. ${ }^{8}$ yaptıkları 20 yıllık retrospektif çalışma sonucunda; sigara içenlerde başarısızlık riskinin 2 kat fazla olduğu, O'Leary plak indeksinde $<\% 10$ aralığındaki hastaların ve Sınıf I restorasyonların ise daha düşük başarısızlık oranı gösterdiği kaydedilmiştir. Anterior dişler üzerine yapılan bir çalıșmada ise başarısızlığın ana faktörlerinin sigara içilmesi, 
içecek tüketimi, bruksizm, kserostomia ve düşük çürük direnci olduğu bildirilmiștir. ${ }^{9}$ Çürüksüz servikal lezyonlar üzerinde yapılan bir çalıșmada ise hastanın sigara tüketimi ve kullanılan adeziv sistemin kompozit performansını etkilemediği belirtilmiștir.10 Hastanın yaşının artmasıyla birlikte restorasyonlar da çeșitli nedenlerden dolayı olumsuz etkilenebilmektedir. 65 yaș üstü bașarısızlık oranı \%10 olan bir çalışmada, çocuklardaki restorasyonların başarısızlık oranı \%4 olarak kaydedilmiştir. ${ }^{11}$

\section{- Restore Edilen Diş İle İlgili Faktörler}

Diş tipinin restorasyonun başarısına etkisi konusunda tutarsız bulgular söz konusudur. Bazı çalıșmalarda premolar dişlere yerleștirilen restorasyonların molar dișlerdeki restorasyonlardan önemli ölçüde ağızda kalma süresinin daha fazla olduğu bildirilmiștir. ${ }^{12}$ Bunun nedeni olarak molar restorasyonun premolardaki restorasyonla karșılaștırıldığında daha büyük okluzal kuvvetlere maruz kalması düşünülebilir. Ayrıca molar dişleri restore ederken çalışma alanına erişimin az olması da bir başka neden olarak sayılabilir. ${ }^{13}$ Lempel ve ark. ${ }^{14}$ ise diş tipinin restorasyon ömrüne/kalitesine anlamlı etkisi olmadığını göstermişlerdir. Namgung ve ark. ${ }^{13}$ çürüksüz servikal restorasyonlar üzerinde yaptığı retrospektif çalıșmada anterior ve molar dișlerin ağızda kalma süreleri anlamlı derecede farklılık göstermiştir (a:11,2 $\pm 0,9 \mathrm{~m}: 8 \pm 1,5$ ). Bu sonuç diș esnemesine neden olan okluzal kuvvetlere bağlanabilir. Başka bir çalışmada ise sekiz yılın sonunda anterior dişlerdeki kompozit rezin restorasyonlarda AFR (yıllık bașarısızlık oranı) daha fazla bulunmuștur. ${ }^{15}$ Aynı çalışmada dişin bulunduğu yerin, okluzal risk faktörlerinin restorasyonun ağızda kalma süresini etkilediği belirtilmiştir. Molar dişlerdeki MOD restorasyonların bu alandaki yük fazlalığı ve restorasyonun genişlemesi nedeniyle dayanıklılık bakımından zayıf olduğu görülmüştür. ${ }^{16}$ YÇ taşıyan çocuklardaki süt dişlerinde yapılan retrospektif çalışmada restore edilen yüzey sayısı, zayıf biyofilm kontrolü ve pulpa tedavisi görmüș olmanın erken çocukluk çağı çürüğü (EÇÇ) olan hastalardaki kompozitlerin ağızda kalma süresini etkilediği gösterilmiștir. ${ }^{17}$ Kök kanal tedavisi (KKT) yapılmış dişler, vital dişlerden farklı biyomekanik ve nöroreseptif davranışlar sergiler. KKT’li dişlerin prognozu doğru restoratif tekniğin seçimine ve çiğneme kuvvetlerine bağlıdır. KKT yapılmış dişler konservatif olarak veya madde kaybı fazla ise protetik olarak restore edilebilir. Uygun restorasyon ile iç streslerin minimuma indirilebileceği bildirilmiștir. ${ }^{18}$ KKT yapılan dişlerdeki restorasyonda kullanılacak 'en iyi'protokolün ve materyalin seçimi ise; kalan diș dokusunun miktarına, periodontal duruma, yapılacak restorasyonların sayısına, koronal ve kök morfolojisine, statik ve dinamik oklüzal temaslara, ağız hijyeni, çürük riski, maliyet ve hastanın sağlık koșullarına göre değişmektedir. ${ }^{19}$ KKT ve hareketli bölümlü protez (HBP) kullanımı yenilenen restorasyonlar için daha yüksek bașarısızlık riski ile ilişsilendirilmiştir. $^{20}$

\section{- Oklüzyon}

Ağız içi muayene edilirken okluzyonu iyi değerlendirmek gerekir. Dişlerde var olan kırıklar, çatlaklar, aşınmış yüzeyler okluzal ilişkiyle ilgili önemli unsurlardır. Dişlerin konumuna göre aşınma farklılık gösterir. Örneğin molar dişler premolar dişlerden daha çok aşınırken, molar dişlerin distal bölgesi de mezial kısmından daha fazla așınmaktadır. Hastada var olan bruksizm gibi parafonksiyonel alıșkanlıklar da kompozit rezinin ve dișin aşınma hızını etkiler. ${ }^{21}$ Restorasyonun gelen kuvvetlere karşı direncini arttırmak amaciyla kompozit rezin restorasyona fiber post yerleștirilebilir. Böylece restore edilen dișin okluzal yükleri absorbe etme yeteneği geliștirilerek direnci arttırılmış olur. Fiber post yerleştirilmesi aynı zamanda daha az kaspal sapmaya neden olacağından diş-restorasyon ara yüzünde boşluk ve bu boşluk nedeniyle oluşacak marjinal sızıntı olasılığını azaltır. Ayrıca minimum 3 yıl içerisinde tüm kaspları kaplayacak restorasyon ile değiștirilmesi beklenmeyen posterior dișlerin direkt restorasyonu esnasında fiber post yerleştirilmesinin tercih edilebileceği bildirilmiștir. ${ }^{22} \mathrm{Bu}$ șekilde restorasyon ömrü ve kalitesinin artırılması amaçlanmaktadır.

\section{- Adeziv Sistem ve Kompozit Uygulama Yön- temi}

Kompozit rezinin diş sert dokularına bağlanabilmesi dental adezivler aracılığıyla olmaktadır. $\mathrm{Bu}$ bağlanma, mikromekanik adezyona dayanmaktadır. Adeziv sistemin etkisi sadece kullanılan materyalin kimyasına değil, aynı zamanda farklı adeziv sistemlerin diş yapılarında meydana getirdiği değişikliklerin bilinmesine ve uygun kullanıma bağlı olarak değișmektedir. ${ }^{23}$ Tek şișe self etch adezivler yüksek konsantrasyonda çözücü içerdiklerinden, bu sistemlerde yeterli kalınlıkta rezin tabakası elde etmek ve artık çözücüyü ortamdan uzaklaștırmak oldukça zordur. Aynı zamanda, yüksek orandaki çözücü içeriği ara yüzde su ağacı oluşumuna sebep olabilir. ${ }^{24}$ Adeziv tabakasında su varlığ sonucunda ise zaman içerisinde polimer ağı şişer, yumuşar ve rezin zayıflar. ${ }^{25}$ Yakın dönemde yapılan bir çalışmada; 2 aşamalı etch and rinse ve 1 aşamalı self etch kullanılarak yapılan restorasyonlarda, 3 aşamalı etch and rinse ve 2 aşamalı self etch uygulanan restorasyonlardan daha fazla bașarısızlık yüzdesi olduğu belirtilmiștir. ${ }^{26}$ Benzer şekilde Mahn ve ark. ${ }^{27}$ yaptığ sistematik bir derlemenin (1955-2012) güncellemesinde ise 2 aşamalı self etch ve 3 aşamalı etch and rinse sistemleri- 
nin tek așamalı self etch'e tercih edilmesi sonucuna ulașılmıștır. Adeziv sistemlerde su yerine etanol kullanıldığında hidrofobik monomerlerin dentine infiltre olabildiği, böylece hibrit tabakanın hidrofobik bir yapıya dönüșmesi sağlanarak daha stabil hale geldiği bildirilmiştir. Ayrıca etanol, çürük dentin yüzeyinden suyun uzaklaşmasını sağlayarak su varlığında aktif olan MMP(Matriks metalloproteinaz) enzimlerinin inaktif hale gelmesine sebep olur. Buna dayanarak etanolün çürük dentinde bağlanmayı geliştirdiğini ileri süren çalışmalar mevcuttur. ${ }^{28}$

\section{- Hekimin Yeteneği ve Tecrübesi}

Hekimin bilgi birikimi ve tecrübesi, restorasyon başarısı ve ömründe belirleyici faktörlerdendir. Her ne kadar diș hekimliği öğrencileri tarafından yapılan posterior restorasyonların ortalama yıllık başarısızlık oranı (AFR) kabul edilebilir bulunsa da, deneyimsiz hekimlerin yaptığı restorasyonların yıllık başarısızlık oranı $(\% 1,7-2,8)^{29}$ deneyimli hekimlerinkine $(\% 1-1,5)^{16}$ kıyasla daha fazla bulunmuştur. Hekimin diş dokularına zarar vermeden çürük bölgeyi ayırt ederek sadece yumuşak çürük kısmını uzaklaştırması büyük önem arz etmektedir. $\mathrm{Bu}$ konuda derin çürüklü dişlerde çürüğün temizlenmesi hakkında çeşitli görüşler ileri sürülmüştür. Casagrande ve ark. ${ }^{30}$ yaptığı retrospektif bir çalışmada "Total Çürük Uzaklaştırma" (complete caries remove-CCR), "Selektif Çürük Uzaklaștırma" (selektive caries remove-SCR) ile karşılaștırıldığında, total çürük uzaklaştırma daha fazla pulpa maruziyetine neden olduğundan, CCR uygulanan dișlerde daha fazla pulpa expozu gözlenmiştir. Pulpa için daha zararlı olduğu belirtilse de restorasyon ömrü bakımından SCR/CCR benzer bulunmuş ve Cox analizinde çürük kaldırma tipinin restorasyonun ağızda kalma süresini etkilemediği gösterilmiştir. Çürük kaldırma esnasinda meydana gelen pulpa maruziyetini uzun süre sonunda daha düșük başarı oranı ile ilișkilendiren çalışmalar mevcuttur. ${ }^{31} 10$ yıl takip süreli bir çalışmada ise pulpal duvarda bırakılmış çürüğün üzerine yapılan adeziv restorasyonun, lezyonun ilerlemesini durdurabildiği belirtilmiștir. ${ }^{32}$ Restorasyon başarısını dolayısıyla ömrünü etkileyen bu faktörlere dikkat edildiği takdirde hasta memnuniyetini sağlayan ideal restorasyonlara ulaşılabilir. Prospektif ve retrospektif kohort çalışmaları içeren derlemede tedavi protokolüne uyulduğu takdirde, kompozit rezin restorasyonların ömrü 15 yıldan fazla olarak belirtilmiștir. ${ }^{9}$

Diş renginde restorasyon için hastanın istekleri, beklentisi, özgüveni, hastaya yeni estetik tercihler sunulması önemlidir. ${ }^{33}$ Diş hekiminin seçimi de birçok faktöre bağlıdır; endikasyon alanı, kullanımı, cilalanması, fiyatı, uzun ömürlülügü gibi. Olumsuz özellikleri azaltmak ve materyali geliştirme adına üreticiler doldurucuların, bağlantı ajanlarının ve matriks kom- ponentlerinin boyutunu, türünü ve içeriğini sürekli değiştirmektedirler. Bu değişimlere bağlı olarak kullanımları ve optik özellikleri gelişirken ${ }^{34}$, aşınma ve kırılma dirençleri artmaktadır. ${ }^{35-37}$ Anterior dișlerde doğru renk eșleşmesinin sağlanması ve polisajlanabilirlik önemli olduğundan pürüzsüzlügü sağlamak için küçük doldurucu partiküller barındıran kompozit rezinler tercih edilir. Ancak bu özellik aynı zamanda materyalin kırılma dayanımının ve elastisite modülünün azalması anlamına gelmektedir. Posterior dişlere uygulanacak kompozit rezinlerde ise aşınma direnci ve kırılma dayanımının yüksek olması istenmektedir. 1980'lerde tanitılan mikrofil kompozit rezinler, renk ve cilalanabilirlik bakımından tatmin edici olmasına rağmen posteriorda kullanılacak kadar dayanıklı değillerdi. Mikrofil kompozit rezinler, sinıf III ve sinıf V labial veneerler ile okluzyonun ayarlanıp kontrol edilebildiği küçük sınıf IV kavitelerde daha başarılı olabilir. Mikrofil kompozit rezinleri ince kompakt dolduruculu olarak tanımlanan, yüksek dolduruculu ve daha büyük partiküller içeren posterior dişlere uygulanmak üzere geliştirilen kompozit rezinler takip etmiştir. Böylece mekanik özellikler iyileştirilmeye çalışılmıştır. 1996'da akışkan kompozitin üretimini takiben 1997'de tepilebilir kompozitler üretilmiştir. 1998'de fiber ilave edilen kompozitler, iyon salabilen kompozitler ve ormoserler üretilmiştir. Ormoser kelimesi; organik modifiye seramik sözcüklerinin ilk hecelerinden oluşur. Așınma hızı düşük olarak bildirilmiştir. ${ }^{38}$ Estetik yönden iyi ve manipülasyonları kolay, polimerizasyon büzülmesi ise azaltılmış kompozitlerdir. Bunları 2002'de nanofil kompozit rezinler takip etmiștir. Nanofil kompozit rezinler, dağılmış halde bulunan doldurucu partiküllerin (5-75 nm) ve silan infiltre edilmiş tamamlanmamış pöröziteli kümenin $(\sim 1.3 \mu \mathrm{m})$ kombinasyonudur; bunlar kompozit rezin matriksi ile birleştirilir ve nano kümeler olarak adlandırılır. Nano kümelerdeki ve boşluklardaki internal pörözitelere silan infiltre edildiğinde, iç içe geçmiş kompozit yapısı oluşturan birbirine bağlı bir yapı oluştuğu bildirildi. Bu yapının mekanik özellikleri diğer kompozit rezinlere kıyasla daha iyidir. ${ }^{39}$ Teknolojinin gelișmesiyle birlikte kompozit rezinlerin kimyasal bileşimi de değişmiştir. Daha düşük büzülme oranl, yüksek reaktivite ve biyouyumlu kompozit rezin üretmek amacıyla yeni bir katyonik halka açma monomer sistemi geliștirildi. ${ }^{40}$

Çeşitli türdeki kompozitler başlıca doldurucu seviyesi, partikül malzemesi, matriks özellikleri ve morfolojideki farklılıklar gibi farklı niteliklere sahiptir. ${ }^{41}$ Farklı yapıda olan kompozitlerden bulk-fill kompozit rezinler, posterior dişlerdeki kavitelere 1 kerede $4 / 5 \mathrm{~mm}$ olacak șekilde yerleştirilerek restoratif prosedürün kolaylaştırılması amaçlanmıştır. ${ }^{42,43} 5 \mathrm{~mm}$ derinliğe kadar ışığın iletilmesi adına daha translu- 
sent yapıdadırlar. Fotoinitiatörleri daha reaktiftir. Polimerizasyon reaksiyonunun modülatör görevini yapan monomerler ihtiva eder ki bu sayede polimerizasyon büzülmesinin düşürülmesi amaçlanmıștır. ${ }^{44,45}$ İki tür bulk fill kompozit rezin bulunmaktadır:

1) Akışkan bulk-fill kompozitler; mikrohibrit/nanohibrit kompozitlerden daha düşük doldurucu oranına sahiptirler ve genelde liner/baz olarak kullanılırlar.

2) Full body bulk-fill rezin kompozitler ise tek tabaka olarak kullanılabilirler.

Yüksek oranda inorganik doldurucu içerdiklerinden, çiğneme yükünün fazla olduğu yerlerde tercih edilebilir. ${ }^{46}$ Pallasen ve ark. ${ }^{47}$ yaptığı çalışmada 27 yıl sonunda bulk-fill tekniğiyle yapılmış kimyasal sertleşen restorasyonların başarısızlık oranı, ışıkla sertleșen kompozitle yapılan restorasyonlardan daha az bulunmuştur. Siloksan ve oksirandan olușan siloranlar ise; renklenme ve polimerizasyon büzülmesi azaltılmış fakat translusentlikleri düşük olduğundan posteriorda kullanımı sınırlı olan kompozitlerdir.

Kompozit rezin restorasyonlarda genel olarak başlıca başarısızlık nedenleri polimerizasyon büzülmesi, kenar sızıntısı, aşınma, postoperatif hassasiyet, renklenme, sekonder çürük oluşumu ve kırık olușumudur. Literatürde posterior kompozitlerde en sık görülen başarısızlık nedenlerinin sekonder çürükler, kırıklar, marjinal eksiklikler ve așınma olduğunu belirten çeșitli çalıșmalar mevcuttur. ${ }^{48,49}$ Diș hekimliğinde kullanılan kompozitlerin hacimsel büzülme oranı \%2-6 arasında değișmektedir. ${ }^{50}$ Monomerlerin polimer yapıya dönüşmeden önceki moleküller arası mesafeleri 0,3-0,4 nanometre iken, polimer haline geçtikten sonra bu mesafe, moleküller arasında kovalent bağların oluşumu ile 0,15 nm'ye düşer. Bu olay polimerizasyon büzülmesi olarak adlandırılır. Büzülmenin büyüklüğü; kompozitin doldurucu miktarı, konversiyon derecesi, kullanılan teknik ve rezin matriks formülasyonuna bağlı olarak değișiklik göstermektedir. Doldurucu hacmi sabit (\%56.7) olan bir rezin içeriğinde doldurucu büyüklüğü ve geometrisindeki değişikliklerin dönüşüm derecesinde \%48-61 aralığında değişim meydana getirdiği bildirilmiştir. ${ }^{51}$ Polimerizasyon büzülmesi sonucunda restorasyon ile çevresindeki diş dokuları arasında yer alan adeziv arayüzde stres meydana gelir. Bunun neticesi olarak sekonder çürükler, marjinal sızıntı, postoperatif hassasiyet oluşabilir. Ekseriyetle sınıf II restorasyonlarda rastlanan bu sorunu azaltmak için polimerizasyon büzülmesine etkili olduğu düșünülen faktörler üzerinde çalışılmıştır. Kavite türü, restoratif materyalin yapısı, polimerizasyon ve yerleștirme tekniği ${ }^{52}$ konularına yönelik çalışmalar yapılmış ve akışkan materyal kullanımı ${ }^{53}$, rezinin tabakalı olarak yerlestirilmesi, alternatif ışık uygulama protokolleri ${ }^{54}$ gibi birçok yöntem üzerinde çalışılmıştır. Tabakalama yöntemleri arasından polimerizasyon stresini, boșluk oluşumunu önlemek ve mekanik özelliklerinin iyileştirilmesi adına inkremental tabakalama tekniği önerilir. ${ }^{55}$ Kompoziti tabakalı yerleștirdiğimiz takdirde, polimerizasyon sırasında kavite duvarları ile minimum temas ile daha küçük hacimlerde kompozit yerleștirilerek büzülme oranında azalma sağlanması ve her bir tabakanın büzülmesinin diğer tabaka tarafindan kompanse edilmesi neticesinde büzülme stresi önemli ölçüde azalmıştır. ${ }^{56}$ Uygulanan ışığın restorasyonun tüm yüzeylerine eşit yayılımı ile homojen bir polimerizasyon sağlanması istenmektedir. Fakat bulk tekniğiyle yerleștirilen restorasyonların servikallerindeki sertlik değeri, okluzalde ölçülen değere kıyasla daha düşük bulunmuştur. İnkremental teknikle yerleștirilen restorasyonlarda ise anlamlı farklılık bulunmamıștır. ${ }^{57}$ Kompozit rezin restorasyonun sızdırmazlığı materyalin kimyasal bileşimine, kullanılan adeziv sistemin tipi ve bağlanma gücüne bağlı olarak değișmektedir. ${ }^{58}$ Adeziv bağlantıda meydana gelen gerilmeler doku bağlanma dayanımını aştığ marjinal bütünlügü bozar. ${ }^{59}$ Sınıf II restorasyonların servikalinde görülen boşluk oluşumunu azaltmak için dikdörtgen kavite preparasyonu yerine küresel preparasyon önerilmiştir. ${ }^{60}$ Işıkla polimerizasyon sırasında büzülme vektörlerini kavite duvarlarına doğru yönlendirme amacıyla ışık yansıtıcı kama ve şeffaf matriks kullanımı tavsiye edilmiștir. ${ }^{61}$ Fakat diş ve kompozit arasında iyi bir bağlantı elde edildiği takdirde büzülmenin bağlanma yüzeylerine yakın bir merkeze yöneleceğini, bu sayede büzülme stresinin zararlı etkilerinin azalacağını bildiren çalıșmalar da mevcuttur. ${ }^{62}$ Literatürde şeffaf bantların kenar uyumu konusunda metal matrikslere klyasla herhangi bir avantajının olmadığını bildiren çalışmalar da mevcuttur. ${ }^{63}$ Kompozit rezin restorasyonlarm her aşaması gibi bitim işlemleri de önem arz etmektedir. Öyle ki, posterior kompozit rezin restorasyonların başlangıç çatlamasına neden olarak bitirme işlemlerini gösteren çalıșmalar mevcuttur. ${ }^{64}$ Kuru șekilde yapılan polisaj, 'beyaz bir çizgi' oluşturarak kenar boșluğunun altındaki kompozit tozu süpürür. Sulu ve yavaş hızda polisajın tercih edilmelidir. Yavaş hızda polisaj da yüksek hızda yapılan polisajdan daha pürüzsüz sonuç verir.

Gönülol ve ark. ${ }^{65}$ yaptığı çalışmada plak akümülasyonu ve hasta alışkanlıklarının sekonder çürük oluşumunda önemli belirleyiciler olduğunu kaydetmişlerdir. Sınıf II restorasyonlarda yapılan meta-analiz sonucunda marjinal çürüklerin minimum 2 yıl sonra gözlenebildiği bildirilmiștir. ${ }^{2}$ Kuper ve ark. ${ }^{66}$ yaptığ 1 çalışmada restorasyonların servikal sınırının genişlemesi ile sekonder çürük prevalansı arasında ilișki olmadığı bulunmuştur. İndirek 
restorasyonlarda sekonder çürük insidansının düșük olması, 20 yıl takip periyodu süresince değișmeden kalan marjinal bütünlükle ilişkili bulunmuștur. ${ }^{8}$ Mikromorfolojik incelemede marjinal boșluklar restorasyonun ilk yılında yarısından fazlasında görülmüș ve bu oran hızla artmışken, 29 yıl sonunda fazla değişmemiştir. Marjinal kırıklar, boşluklar ve negatif çıkıntıların sekonder çürüğe katkıda bulunmadığı bildirilmiştir. ${ }^{67} \mathrm{Bu}$ sonuç, negatif kenarların varlığında bile çiğneme ve ısırmaya bağlı aşındırıcı kuvvetlerin (diş-diş teması) çiğneme dengesine, periodontal rejenerasyona, fizyolojik plak kontrolüne katkıda bulunması ile açıklanabilir. Kompozit rezin restorasyonlarda sık görülen bir diğer başarısızlık nedeni kırık oluşumudur. Hasta yașı ve restore edilen yüzey sayısı kırık oluşumunu etkileyen faktörlerdir. 55-96 yaș aralığındaki hastalarda materyalin kompozit/amalgam olmasına bakılmaksızın, 18-54 yaș aralığındaki hastalara kıyasla daha fazla kırık oluşumu tespit edilmiștir. ${ }^{68}$ Bunu önlemek adına kompozit rezinler geliștirilmeye devam edilmektedir. Son yıllarda bileşik karışıma dahil edilmiş bir benzoil peroksit katalizörü olan TEGDMA monomeri ve $\mathrm{N}$, N-dihidroksietil-p-toluidin (DHEPT) amin hızlandırıcısının (her ikisi de bir iyileștirici ajan olarak) PUF (Poly Urea-Formaldehyde) mikro kapsülleri ile kendi kendini iyileștiren kompozitler (SHDC) geliştirilmiştir. Bileşik kırık sonrası mikrokapsül kullanılan bir çalışmada kendi kendini iyileștirme ve kırılma dayanımının geri kazanımı $\% 65^{69}$ olarak bildirilirken, bir diğer çalışmada kırık sonrası kompozit rezinlerde iyileşme \%25-80 olarak rapor edilmiștir. ${ }^{70}$ Kendi kendini iyileștirme sistemleri, çatlak inhibisyonu ve kendiliğinden onarım için umut vericidir. Literatürde restorasyonlarda kırık oluşumunu restorasyon altına yerleştirilen kaide/astar ile ilişkilendiren çalışmalar da mevcuttur. Uzun dönem çalışmalarda kaide/astarın kullanıldığı restorasyonlarda nispeten daha fazla kırık oluşumu tespit edilmişken ${ }^{71}$ astarsız kompozit restorasyonlarda daha az kırık rapor edilmiştir. ${ }^{72}$ Akıșkan kompozit rezinlerin doldurucu oranlarının düșük olmasına bağlı olarak daha fazla ekzotermik reaksiyon gösterdikleri dolayısıyla polimerizasyon sırasında daha fazla ısı artışı meydana geldiği bildirilmiştir. ${ }^{73}$ Akışkan kompozit rezinlerin elastik modülünün düșük olmasından dolayı stresi absorbe edeceği fikrine dayanılarak snowplow tekniği geliştirilmiştir. "Posterior class II kompozit restorasyonların gingival basamağına 0,25 mm akıcı kompozitle kaide yapılması" șeklinde olan snowplow tekniğinin kullanıldığı ve 4 yıl takip edildiği retrospektif çalışmada ise akışkan kompozit kullanımının posteriordaki kompozit restorasyonların ağızda kalma süresini etkilemediği rapor edilmiştir. ${ }^{74}$

Tanner ve ark. ${ }^{75}$ hasta yaşı ve restore edilen yüzey sayısının anatomik form üzerinde önemli etki- ye sahip olduğunu, marjinal renk bozulmasını etkilediğini ve büyük restorasyonların daha yüksek AFR'ye sahip olduğunu bildirmişlerdir. Pallesen ve Dijken ${ }^{7}$ 'in yaptığı 30 yıllık retrospektif çalıșma sonucunda posterior kompozitlerde ana klinik problemin okluzal aşınmadan dolayı anatomik formun kaybedilmesi olduğu belirtilmiștir. Ağız ortamında, restoratif materyalin yüzeyinin bozulması ve boya maddelerinin emilimi rengin bozulmasına neden olabilir. Renk değişimi rezin matriksin içeriği ile de ilişkili olabilir. Düşük miktarda TEGDMA varlığı su alımını ve dolayısıyla boya çözeltisinin emilmesiyle renk değişimini sınırlayabilir. ${ }^{76}$ Başlangıçta restore edilen yüzey sayısı, sonrasında restorasyonun başarısızlığını tahmin etmede yardımcı olabilir. Opdam ${ }^{77}$, a göre restore edilen yüzey sayısı restorasyon ömründe major rol oynar. Anterior dișlerde nanofil ve mikrohibrit kompozitlerin kullanıldığı bir çalıșmada ise restorasyon büyüklügü ve tipi, sigara kullanımı ve bruksizmin restorasyon bozulmasinda etkili olmadığı bununla birlikte çay, kahve ve kola tüketiminin nanodolduruculu restorasyonun renk uyumunu doğrudan etkilediği kaydedilmiştir. ${ }^{78}$ Uzun dönem bakıldığında kullanılan kompozit tipinin restorasyon ömründe temel etken olmadı̆̆ gözlenmiştir.,49 Posteriorda indirek kompozitler üzerinde yapılan, 20 yıl takip süreli retrospektif çalışmada ise restorasyon ömründe "çürük riskinin" ana rol oynadığı belirtilmiștir. ${ }^{8}$ Restorasyon ömrünün uzun olması, restorasyonun en önemli bașarı parametrelerinden biridir. Böylelikle hasta memnuniyeti artar, yenileme/tamir aşamaları elimine edilmiş olur ki ekonomik açıdan da olumlu bir katkısı mevcuttur. Bașarısız olan restorasyonların tedavisinde çeșitli tedavi protokolleri bulunmaktadır. Defektin büyüklügüne göre restorasyon takip edilebilir veya tamir, değişim, parlatma işlemi uygulanır. ${ }^{80}$ Restorasyonun her değiștirilme sürecinde kavite preparasyonunda 0,2-0,6 $\mathrm{mm}$ büyüme meydana geldiği belirtilmiştir. ${ }^{80}$ Fakat yine de restorasyonların çeşitli nedenlerle değiştirilmesi diş hekimleri tarafından yapılan tedavilerin yarısını oluşturmaktadır. ${ }^{81} 300.000$ 'den fazla hastayı kapsayan bir kohort çalışmada, posterior amalgam ve kompozit rezin restorasyonların 5 yl sonunda ağızda kalma olasılığının \%90'dan fazla iken hastalar diș hekimini değiștirdiği takdirde bu oranın \%60'a düştüğü rapor edilmiștir. ${ }^{82}$ Daha çok kırık sebebiyle yapilmakta olan restorasyon tamirlerinde, orijinal restorasyonun kalan kısımlarının onarılan kısımdan daha yüksek başarı oranı gösterdiği bulunmuştur. ${ }^{20}$ Ayrica tamir, restorasyonun tamamen değiştirilmesinden daha kabul edilebilir, hızlı ve daha ekonomik bir yöntemdir. Yenilenen kompozit rezin restorasyonların ortalama 6 yll ömrünün olduğunu belirten çalışmada, en kısa restorasyon ömrü sınıf II restorasyonlarda gözlenirken; en uzun ömürlü restorasyon türünün sinıf III restorasyonlar olduğu 
bildirilmiștir. ${ }^{1}$ Tamir gerektiren durumlarda restorasyonun kalan kısmı ile eklenecek kompozit rezin arasındaki bağın iyileştirilmesi amacıyla yüzey pürüzlendirmesi önerilir. Eski kompozit rezin restorasyonda yapılan yüzey işlemi ile tükürük ile değişmiş yüzeysel tabakayı uzaklaştırmak ve yüzey düzensizlikleri olușturarak yüzey alanını artırmak amaçlanır. ${ }^{83}$ Yüzeyi pürüzlendirmede elmas frez veya air abrazyonla mekanik pürüzlendirme, kumlama ile mekanokimyasal pürüzlendirme veya fosforik asit gibi asitlerle kimyasal pürüzlendirme yapılabilir. ${ }^{84}$ Şayet tamir edilecek kompozit materyalin içeriği bilinmiyor ise fosforik asit, kumlama (alüminyum oksit), silan ve adeziv sistemlerin kullanımı önerilir. ${ }^{85}$ Yüzeyi pürüzlendirmede elmas frez ve kumlamanın en yüksek bağlanma dayanımı gösterdiği belirtilmiştir. ${ }^{86}$ Adeziv sistemlerden ise self etch sistemler kullanıldığında tamirde en yüksek bağlanma dayanımı elde edilmiștir. ${ }^{87}$ Tamir sonucu elde edilen bağlanma dayanımının 18 MPa'dan fazla olması istenmekte$\operatorname{dir}^{88}$ Literatürde kompozit rezin tamirinde silan ve self etch adezivlerin kullanılmamasını öneren çalışmalar da mevcuttur. ${ }^{89}$

Restorasyonun başarısızlı̆̆ı kapladığı yüzey sayısı ile dikkate değer şekilde ilişkilidir. İnterkaspal mesafenin 1/4'ünden fazla genişlikte olan MOD preparasyonların kırılma direncinin önemli ölçüde azaldığını belirten çalışmalar mevcuttur. ${ }^{90}$ Universal kompozitlerle yapılan çalışmada anterior dişlerde restore edilen yüzey sayısının ağızda kalma süresi üzerine anlamlı etkisi bulunmazken, posterior dişlerde dikkate değer șekilde anlamlı bulunmuștur. Dört veya daha fazla yüzey içeren restorasyonun başarısızlık riski; tek yüzlü restorasyonlardan 11 kat, 2/3 yüzlü restorasyonlardan 2 kat fazla bulunmuştur. ${ }^{91}$ Bir başka çalışmada ise dört veya daha fazla yüzey içeren restorasyonlar, tek yüzlü restorasyonlardan $4 \mathrm{kez}$ daha fazla başarısızlığa eğilimli bulunmuştur. ${ }^{11}$

Kompozit çeşitlerinden biri olan mikrohibrit kompozitlerden dördü ile yapılan çalışmada 10 yılın sonunda elde edilen bulgulara göre; Renew kompozit rezinin (Bisco Inc., Schaumburg, II, USA) daha düşük kırılma dayanımına sahip olduğu bunun nedeninin de daha düşük doldurucu hacmiyle ilişkili olan düşük elastisite modülünden dolayı olduğu söylenebilir. Gradia kompozit rezin materyali (GC America, Inc., Alsip, II, USA) renk eşleşmesinde en fazla değişiklik gösteren mikrohibrit kompozit rezin olmuştur. Bu durum, rengin değişmesine neden olabilecek ortalama partikül büyüklügünün daha büyük olması ile açıklanabilir. ${ }^{14}$ Ayrıca, reaksiyona girmemiş matriks monomerlerinin, fotoinitiatör ve koinitiatörlerin miktarı da kompozitin renginin bozulmasında önemli bir etkiye sahiptir. Malzemenin türünden bağımsız olarak, üç yüzlü kompozit restorasyonda anlamlı derecede daha fazla marjinal renk değişimi ve anatomik form eksiklikleri bulunmuştur. Bu durum, aşındırıcılara maruz kalan ve madde kaybına yol açan kompozit yüzeyinin fazla olması ile açıklanabilir. Borgia ve ark. ${ }^{92}$ yaptı̆̆ çalışmada, mikrohibrit restorasyonlarla karşılaştırıldığında klinik olarak nanofil ve mikrofil restorasyonlar benzer ve mikrohibrit restorasyonlardan daha başarılı bulunmuştur fakat bu fark anlamlı değilken; mikrofil kompozit rezin anlamlı şekilde daha uzun ömürlü bulunmuştur. Anterior dişlerde yapılan bir çalışmada ise mikrohibrit kompozitle yapılan restorasyonlarda nanofil kompozitle yapılandan 3,7 kat daha sık kırılma görülmüștür. Nanofil kompozit kullanılan restorasyonlarda ise renk uyumsuzluğu 8,3 kat daha fazla gözlenmiştir. ${ }^{78}$ Nanofil kompozit rezinler dayanıklılı̆̆ı ve azaltılmış polimerizasyon büzülmesi nedeniyle genellikle geniș posterior restorasyonlarda tercih edilir. ${ }^{41}$ Sinıf II restorasyonlarda yapılan bir çalışmada retansiyon ve marjinal adaptasyon bakımından nanohibrit kompozit rezinler mikrofil kompozit rezinlerden üstün bulunmuștur. ${ }^{93}$ Teknolojideki gelişmelerle birlikte smart kompozitler adı altında kendini onarabilen kompozit rezinler, ACP (Amorf Kalsiyum Fosfat) bazl kompozit rezinler, antimikrobiyal kompozit rezinler üretilmiştir. ACP bazlı kompozit rezinler ağız boşluğunda kalsiyum ve fosfat salarak apatit oluşumunu tetikler fakat polimerizasyon büzülmesinin fazla olması ve mekanik özelliklerinin yetersiz olușundan dolayı geliștirilmesi gerekmektedir. ${ }^{94}$ Sekonder çürüklerin kompozit rezinlerde en sık gözlenen başarısızlık türlerinden biri olmasından dolayı üreticiler bunu önlemek adına kompozit rezinlerin içerisine klorheksidin ve gümüş partikülleri eklemiştir. ${ }^{96}$ Kompozit rezinlere gümüş nanopartiküllerin eklenmesinin biyofilm büyümesini azalttığı rapor edilmiștir. ${ }^{95}$ Kompozitin aşınmasının doldurucu partikül ile ilişkili olduğu, özellikle doldurucu partikülün içeriği ve boyutuna ve rezin formülasyonuna bağlı olduğu bilinmektedir. Kompozit rezin bileşiminde yer alan doldurucular sayesinde aşınmaya karşı daha dirençli, daha yüksek mikrosertlik ve daha iyi mekanik özellikler sergileyebilmektedir. Son zamanlarda mini dolduruculu, hibrit ve nanohibrit kompozit rezinler gibi yeni nesil restoratif materyallerde yüksek miktarda küçük doldurucu partikül bulunduğundan aşınma direncinin arttığı bilinmektedir. Restoratif materyalin aşınması restoratif materyalin sertliği, kavite dizaynı ve değerlendirme zamanı gibi etkenlere bağlı farklılık göstermektedir. Nanohibrit kompozitler hibrit kompozitlerin fiziksel gücü ve aşınma direnci ile mikrofil kompozitlerin uygulanabilirlik ve cilalanma özelliklerinin birleștiği kompozitlerdir. Baryum alüminyum silikat doldurucular, ytterbium triflorid ve karışık oksitler içerdiği için aşınma direnci artmıştır. Handa ve ark. ${ }^{96}$ nanohibrit kompozitlerin Knoop sertlik değerini mikrofil kompozit rezinden daha fazla olarak 
bildirmișlerdir. Sınıf I kavitelerde yapılan çalıșmada nanohibrit kompozitin mikrofil kompozitten istatiksel olarak anlamlı șekilde daha az aşınma gösterdiği rapor edilmiştir. ${ }^{97}$

Ekseriyetle, restore edilecek kavitenin büyüklüğü posterior dişlerdeki tekniğin seçiminde belirleyici olmaktadır. Bu seçimde isthmus genişliğinin bukkal ve lingual kasplar arasındaki mesafenin üçte ikisini aştığı geniş kavitelerde indirek yöntem öne çıkar. ${ }^{98-100}$ Direk restorasyonlarla karşılaştırıldığında, küçük ve orta büyüklükteki çürük lezyonlarının tamirinde, kompozit indirek restorasyonlar ile daha iyi anatomik şekil, mükemmel okluzal morfoloji, daha iyi kontak sayesinde marjinal adaptasyonun daha iyi elde edilme ihtimali yüksektir. ${ }^{101}$ İndirek kompozit restorasyonların oklüzal ve gingival bölgelerindeki kenar sızıntısı değerlerinin, direkt kompozit restorasyonlardan daha az olduğunu bildirilmiştir. $^{102}$ İndirek restorasyonların diğer avantajları ise materyalin büzülmesinin önlenme olasılığı, kırıklara karşı daha yüksek dirence sahip olması ve çok iyi biyouyumluluğunun olmasıdır. Böylelikle direk restorasyonların dezavantajlarına alternatif geliştirilmiş olmaktadır. Öyle ki direk restorasyonlarda polimerizasyon büzülmesinin indirek restorasyonlardan 13 kat fazla olduğunu bildiren çalışmalar mevcuttur. ${ }^{103}$ İndirek adeziv restorasyonların daha düşük AFR değerine sahip olduğu savunulmaktadır. ${ }^{48}$ Van Dijken ${ }^{104}$ 11 yıllık takip sonucu bașarısızlık oranının indirek restorasyonlarda (\%17.7) direkt restorasyonlardan (\%27.3) daha az olduğunu bildirmiştir. Bresser ve ark. ${ }^{105}$ derin marjin elevasyonu ile indirek çalıșma sonucunda indirek restorasyonların ağızda kalma süresini etkileyen en önemli faktörün restorasyon büyüklügü olduğu bildirmişlerdir. Torres ve ark. 106 direk/semidirek tekniği kullandığ postoperatif hassasiyet direk teknikle yapılan restorasyonlarda, marjinal kırık semidirek teknikle yapılan restorasyonlarda daha fazla gözlenmiștir. Literatürde indirek restorasyonların așınma dirençlerinin düșük olduğu bildirilmiștir. ${ }^{107}$ Da Veiga ve ark. ${ }^{108}$ sistematik incelemesinde ise sinıf I ve sinıf II kavitelere yapılan direk/indirek restorasyonların ömrü bakımından farklılık bulunmamış ve daha az çaba ve maliyeti olan direk restorasyonların tercih edilmesinin daha makul olduğu belirtilmiştir.

İndirek restorasyonların seans sayısının fazla olma$\mathrm{Sl}$, hasta koordinasyonu gerektirmesi hekimleri yeni yöntem arayışına yönlendirmiştir. Bilgisayar destekli tasarım ve üretim (CAD/CAM) teknolojisi son 35 yıldır diş hekimliğinde yükselişe geçmiş, bilgisayar destekli restorasyon tasarımı ve üretimine olanak sağlamıștır. Bu sistem popülerlik kazandıkça CAD/ CAM'e uyarlanmıș restoratif materyaller de çeșitlilik kazandı. ${ }^{109}$ Yeni geliştirilen nanohibrit rezin kompozitlerle CAD/CAM endikasyonları inley ve onleylerden tam kapsamlı kronlara genişletilmiştir. CAD/CAM'de kullanılan kompozit bloklar yüksek derecede polimerizasyon gösterirler. Bu özellik aynı zamanda bu materyallerin dezavantajıdır. Yüksek polimerizasyon derecesinden dolayı rezin bloklar ile adeziv rezin siman arasında bağ kurmak güçleşmektedir. Ağırlıkça \%60 silika tozu ve inorganik dolduruculardan oluşur ve bu haliyle konvansiyonel kompozit rezinlerden daha iyi fiziksel özelliklere sahiptir. ${ }^{110}$ Shembish ve ark. ${ }^{111} \mathrm{CAD} / \mathrm{CAM}$ ile hazırlanmış molar kompozit kronların lösit takviyeli molar cam seramik kronlardan daha iyi yorulma direncine sahip olduğunu belirtmişlerdir. Bir başka çalışmada Lava Ultimate (3M ESPE, USA) nano seramik rezin kompozitten yapllan posterior okluzal veneerlerin Paradigm MZ100 (3M ESPE, USA)'den daha üstün kırılma direnci ile okluzal yükler karşısında daha uzun ömürlü olduğu sonucuna varılmıştır. ${ }^{112}$

Restorasyon için seçilecek materyallerin çeşitli avantajları ve dezavantajları bulunmaktadır. Önemli olan doğru materyali doğru endikasyonda, prosedürlerine uygun şekilde kullanmaktır. Hangi restoratif materyalin kullanılacağı hekim tarafından belirlenir. Hekimin mezuniyetinden itibaren geçen süre ve uzmanlık düzeyi ile ilişkili olarak materyal tercihi değişebilmektedir. Genellikle materyalin kullanım özellikleri, dayanıklılığı, aşınma direnci, özellikle anterior dişler için de estetik özellikleri bu seçimde belirleyici olmaktadır. Farklı sağlık düzenlemeleri (sigorta veya hasta tarafından karşılanması) de önemli bir faktördür. Kavite tipi ise restoratif materyal seçimini etkileyen bir diğer faktördür. Örneğin servikal lezyonlar için kompozitler yeterli dayanıklılığa sahipken kullanımda izolasyon, dentin marjinine bağlanma zorlukları gibi çeşitli zorluklar söz konusudur. En uygun restoratif materyal seçildiğinde hekim için zaman tasarrufu sağladığı gibi hasta için koltukta geçirilen süre azalır, restorasyon ömrü ve dolayısıyla hasta memnuniyeti de artar. Bu amaçla çeşitli restoratif materyaller ile farklı sınıf kavitelerde çalışılmış ve halen çalışılmaya devam edilmektedir.

Literatürde servikal lezyonlarda marjinal adaptasyon, renk değişimi ve retansiyon unsurları birlikte değerlendirildiğinde kompozit rezinlerin cam iyonomerden üstün bulunduğu ve klinik performans bakımından işlevdeyken kompozitin CíS(cam iyonomer siman)'den üstün olduğunu ${ }^{13}$ bildiren çalışmalar yer almaktadır. CİS diş dokularına fizikokimyasal bağlanması, florür salınımı, büzülmesi ile marjinal sızıntısının düşük olması, restorasyon kenarlarında antikaryojenik oluşu gibi avantajlara sahiptir. ${ }^{113}$ Restoratif materyalin diş yapılarına retansiyonu başlıca başarı kriterlerindendir. Amerikan Diș Hekimleri Birliği 18 ay sonunda \%90 retansiyon oranını kabul edilebilir olarak bildirmiştir. ${ }^{114}$ Çürüksüz servikal lezyonlarda kısa (1-3 yıl) ve uzun ( 5 yıl) dönem takip neticesin- 
de cam iyonomer ve rezin modifiye cam iyonomerin retansiyonu kompozitten daha fazla bulunmuștur. ${ }^{115}$ Çürüksüz servikal lezyonlar hakkındaki başka bir çalışmada ise self etch uygulamasından önce mineye asit uygulanmasının retansiyonu artırdığı, kompozit rezin restorasyonların daha uzun ömürlü olduğu belirtilmiştir. Ayrıca bu uygulama sayesinde marjinal renk değișimi azalmıș, marjinal bütünlüğün daha iyi korunduğu görülmüștür.116 "Glass ionomer + polimer"sözcüklerinin birleşimiyle türetilen Giomerler ${ }^{117}$ kompozitlerden daha fazla su emilimi ve renklenme gösterdiği için estetik özellikler bakımından daha zayıf bulunmuştur. ${ }^{118}$ Kompleks yapıda CİS türevi olan ${ }^{119}$ cam karbomerler toz kısımlarında ek olarak hidroksiapatit ve kalsiyum floroapatit kristalleri barındırır. Kırılma ve așınma dirençlerinin CİS ve RMCIS'dan fazla olduğu bildirilmiștir. ${ }^{120}$ Geleneksel cam iyonomerlerin aşınma ve kırılma dirençlerinin düşük olması, nem hassasiyeti ve estetik yönden zayıf olması gibi dezavantajları vardır. Bilindiği gibi ara yüzler ve diș eti bölgelerinde biyofilm olușma ihtimali daha fazladır. Bunu önlemek adına bu bölgelerde bakteriler için adeziv özelliği düşük materyaller kullanılabilir. S. Mutans adezyonu bakımından akışkan kompozit, mikrohibrit kompozit, cam iyonomer, kompomer ve ormoser şeklinde artan bir sıralama bildirilmiştir. Aynı çalışmada \%3 MPC (methacryloyloxyethyl phosphorylcholine) içeren kompozit rezinlerde RMCIS ve amalgama benzer miktarda biyofilm oluștuğu bildirilmiștir.121 Premolar dișlerdeki MOD kavitelerde yapılan çalışma sonucunda kompozitin kırılma direncinin CİS ve RMCIS'dan daha yüksek olduğu bildirilmiștir. ${ }^{122} \mathrm{Bu}$ durum kompozitin adeziv özelliği ile kaspları birbirine bağlayarak olabilecek fleksiyonları azaltmasına atfedilebilir. Son ylllarda bu dezavantajları iyileştirmek için toz/ sıvı oranı, parçacık boyut ve dağılımı değiştirilerek daha güçlü hale getirilmiş, yüksek vizkoziteli CİS olarak piyasaya sürülmüştür. ${ }^{123,124}$ Üzerine ise yüzey örtücü rezin uygulanması önerilir. Bu uygulama ile yüzey parlaklığı artar, bitirme işlemlerinin neden olduğu olası boșluklar doldurulur, sertleșmenin erken dönemlerinde görülen hassasiyet azalır ve mekanik özellikler iyileștirilmiş olur. ${ }^{125}$ Yüksek viskoziteli cam iyonomerlerin sertleşme reaksiyonu geleneksel cam iyonomerlere göre hızlı olduğundan erken dönemde fiziksel özellikleri olumsuz etkilenmez. Yüksek viskoziteli CİS'lerin kullanıldığı süt ve daimi posterior dişlerde yapılan iki ayrı çalışmada, sınıf II restorasyonların radyografik incelemesinde restorasyonların proksimal duvarında konkavite bildirilmiştir. ${ }^{126,127}$ CÍS, metal matrikse kimyasal olarak yapışabilir ve matriks çlkarılırken uygulanan kuvvet nedeniyle CİS'da mikroçatlaklar oluşabilir. Mikroçatlaklar nedeniyle restorasyon kimyasal saldırılara karșı duyarlı hale gelebilir. ${ }^{127}$ Renk uyumu açısından her ne kadar kompozit rezinler üstün olarak bilinse de yüksek viskoziteli CİS'in zamanla translusentliğinin artarak renk uyumunun iyileștiğini bildiren çalıșmalar mevcuttur. ${ }^{128}$ İki yll takip süresi sonunda geleneksel kompozit rezin ve bulk fill kompozit rezin benzer klinik performans göstermiș ve klinik olarak cam hibrit materyalden(Equia Forte) daha başarılı bulunmuştur. Ayrıca sınıf II kavitelerin daimi restorasyonunda yüksek viskoziteli CİS kullanılmasının uygun olmadığı sonucuna ulaşılmıștır. ${ }^{129}$ RMCIS ve kompozitin olumlu özellikleri birleştirilerek geliştirilmiş RMCISS (ACTIVA) piyasaya sürülmüștür. Bu materyalin yapısında kompozitlerden farklı olarak Bisfenol $A$ ve BISGMA yer almaz. Bükülme direncinin akışkan kompozitle benzer olup CİS ve RMCİS'den yüksek olduğunu bildiren çalışmalar mevcuttur. Fakat yeni bir ürün olduğundan yeterli sayıda çalışma bulunmamaktadır. ${ }^{130}$ Daimi dişlerde olduğu gibi süt dişlerinde de kompozitin başarılı bulunduğu çalışmalar göze çarpmaktadır. Başarısızlık riski bakımından kompozitle karşılaştırıldığında RMCİS:1,16, CíS:1,86 kat daha yüksek riske sahip olarak bulunmuştur. Süt dişlerinde 4 yll sonunda AFR kompozit için:\%9,5 iken; RMCIS:\%12,2 ve CIS:\%12,9 şeklindedir. ${ }^{131}$ Amelogenezis imperfektalı (Aİ) genç hastalarda $(<18)$ yapılan çalışmada ise cam iyonomer ile kompozit arasında restorasyon ömrünün uzunluğu bakımından bir fark bulunamamışken, kompozit restorasyonun ağızda kalma süresi Aİ'nın hipoplastik formunda, anlamlı olarak hipomineralize/hipomature formundan daha fazla bulunmuştur. ${ }^{132}$

Amalgam interfasiyal marjinlerde sızdırmaz oluşu, basınca karșı diş yapılarına benzer dayanıklılık ve kırığa karşı yeterli direnç gösterme gibi niteliklere sahiptir. Amalgam çeşitlerinden daha çok yüksek bakır içerikli amalgamlar tercih edilmektedir. Yüksek bakır içerikli amalgam kullanılan restorasyonların ömrü, kaspları içeren geniş kavitelerde 12 yıldan fazla olarak bildirilmiştir. ${ }^{133}$ Amalgam ile yıllardır süregelen kompozit kıyaslamasında da çeşitli çalışma ve görüşler mevcuttur. Amalgamın kompozit rezinden daha az aşınma gösterdiği bilinmektedir. ${ }^{134}$ Fakat kompozit rezinler teknolojideki ilerlemeye paralel olarak gelişmektedir. 2006 yılında yapılan çalışmada 3 yıl sonra minedeki aşınma miktarı 122 mikrometre iken mevcut kompozit rezinlerde 110-149 mikrometre aralığında mine yapısına benzer aralıkta bulunmuştur. ${ }^{135}$ Bernardo ve ark. ${ }^{72} 7$ yll takip süreli çalışmaları sonucunda kompozit rezin restorasyonların ortalama yıllık başarısızlık oranının amalgam restorasyonlardan 3 kat fazla olduğunu bildirmişlerdir. $^{72}$ Fakat kompozit rezinlerdeki gelişmelerle birlikte restorasyonların ağızda kalma sürelerine bakıldığında kompozit rezin ve amalgamın benzer olduğunu bildiren çalışmalar mevcuttur. Kompozit rezinin ağızda kalma oranının 5 yıl sonunda \%91,7, 10 yll sonunda \%82,2 olduğu çalışmada amalgam için 
bu oranlar \%89,6 ve \%79,2 olarak bildirilmiștir. ${ }^{136}$ $\mathrm{Bu}$ materyallerle yapılan restorasyonların yıllık başarısızlık oranı kompozit rezin için \%0-7, amalgam için \%0-9 aralığında bildirilmiștir. ${ }^{137}$ Kenarları minede sonlanan restorasyonlarda, düşük risk grubundaki hastalarda ve tam izolasyon sağlanabildiğinde kompozit rezinlerin tercih edilmesi önerilmiştir. Aynı çalıșmada kenarları dentin ve sementte sonlanan, geniş kavitelerde ve izolasyon sağlanamadığında amalgamın tercih edilmesi gerektiği bildirilmiștir. ${ }^{138}$ Okluzal ve okluzoproksimal posterior restorasyonlarda amalgamın daha uzun ömürlü olduğunu belirten çalışmada, sekonder çürük oluşumu kompozit restorasyonlarda önemli ölçüde daha yüksek bulunmuş, kırık bakımından ise istatiksel fark gözlenmemiștir. ${ }^{139} \mathrm{Bu}$ derlemede en son inceleme 2013 yılında yapıldığından, kompozitlerin fiziksel ve mekanik performansındaki sürekli iyileşme dikkate alındığında kompozitin kalitesini etkilediği düşünülebilir. Kuper ve ark. ${ }^{66}$ yaptığı çalışmada, düşük çürük riskli hastalarda büyük aproksimal restorasyonlarda kompozitin amalgamdan daha başarılı olduğu gözlenmiştir. Sınıf II restorasyonlarda yapılan retrospektif çalışmada ise amalgam uzun vadede artan başarısızlık oranına sahipken; kompozitin özellikle düşük çürük risk grubunda yer alan hastalarda sabit başarısızlık oranı gösterdiği bulunmuştur. Yüksek çürük risk grubunda yer alan hastalarda küçük restorasyonlarda amalgam bașarılı iken, düșük ve kombine risk grubundaki hastalarda kompozitin bașarılı olduğu belirtilmiştir. Ayrıca kompozitle restore edilmiş dişlerdeki kırık oranı daha azdır. ${ }^{140} \mathrm{Bu}$ sonuç adeziv restorasyonların diș yapısını güçlendirdiği hipotezini destekler niteliktedir. KKT'li dişler daha kırılgan ve dayanıksız olmakla birlikte restorasyon yüzey sayısının artmasıyla başarısızlık ihtimali artış göstermektedir. KKT yapılmış dişlerde porselen, kompozit rezin ve amalgam ile yapılan restorasyonların oluşturduğu stres değerleri ölçüldüğünde en fazla stres değeri amalgam restorasyonlarda gözlenmiştir. ${ }^{141}$ Kompozit rezin teknolojisindeki gelişmeler direkt restorasyonlarda kompozit rezinin tercih edilen materyal olması konusunda umut vericidir.

\section{REZIN KOMPOZİTLERDE KLİNİK ÇALIŞMALAR}

Restoratif materyalin uygulanmasından itibaren geçen süreçte materyalin performansını ve durumunu etkileyebilecek çok sayıda değişken olmasından dolayı gerçek klinik performansını belirlemek zordur. $\mathrm{Bu}$ konuda farklı türde çalışmalar yapılmaktadır. Prospektif çalışmalar daha fazla sayıda katılımcı çıkarılması, çalışmaya katılmada zorluk, ekonomik açıdan maliyetli olması ve hekimin yeteneğinde değişiklik gibi dezavantajlara sahiptir. ${ }^{142}$ Retrospektif klinik çalışmalar; daha geniş hasta grubu üzerinde çalışma imkanı sağlaması, düşük maliyetli olması ve uzun bir zaman aralığında restorasyonların ağızda kalma sürelerini incelemek için daha uygun olduğundan tercih edilmektedir.

Kompozit restorasyonlarla ilgili yayımlanan makalelerin derlemesinde;

- PubMed,

- American College Of Prosthodontics,

- Journal Of Dentistry,

- Journal Of Prosthodontic Research,

- Dental Materials,

- The Open Dentistry Journal,

- jdr.sagepub.com,

- dergipark.gov.tr,

- Neurotoxicology,

- European Journal of Prosthodontics and Restorative Dentistry,

- Operative Dentistry,

- Operative Dentistry and Endodontics,

- ulakbim.gov.tr,

- tez.yok.gov.tr,

- Google Akademik,

- Science Direct gibi çeşitli kaynaklardan yararlanıldı.

Bu derlemede, incelenen 74 makale içerisinde 2010 yılından itibaren yayınlanan makaleler dikkate alınarak yapılan eleme neticesinde, 43 makaledeki veriler tablo haline getirildi.

İncelenen makalelerde hasta sayısı aralığı çeşitlilik göstermekle birlikte en fazla görülen hasta sayısı on yedi makale ile 50-100 hasta aralığındadır (Gönülol ve ark., 2018; Lempel ve ark., 2017; Pousette Lundgren ve Dahllöf, 2014; Frese ve ark.,2013; Montag ve ark.,2018; Borgia ve ark., 2017; Baldissera ve ark., 2013; Van Dijken ve Pallesen, 2013; Çetin ve ark., 2013; Diem ve ark., 2014; Dietz ve ark., 2014; Kuper ve ark.,2011; Da Rosa Rodolpho ve ark., 2011; Huth ve ark., 2011; Priyonk ve ark.,2016; Boruziniat ve ark., 2019; Balkaya ve Arslan, 2020). Sadece bir makalede 500-550 hasta ile restorasyonlarm klinik başarısı değerlendirilmiştir (Ravasini ve ark., 2018). Yaş dağılımı bakımından en fazla altı makale ile 18 yaş üstü hasta içeren çalışma mevcuttur (Tabassum ve ark.,2019; Çakır ve Demirbuga, 2018; Moraschini ve ark., 2015; Bresser ve ark., 2019; Namgung ve ark., 2013; McCracken ve ark., 2013; Serrano ve ark., 2013; Jiang ve ark., 2010; Çetin ve ark., 2013; 
Balkaya ve Arslan, 2020; Montagner ve ark., 2018). En az ise 25-35 yaş aralığında çalışma yer almaktadır (Lempel ve ark., 2017; Pallasen ve Van Dijken, 2015; Al Samhan ve ark., 2010; Ozakar ve ark., 2013; Frese ve ark.,2013). Yapilan restorasyon dağılımında ise en az çalıșma 2000-5000 restorasyon aralığındadır ( Moraschini ve ark., 2015). En fazla çalışma ise 50-150 restorasyon aralığında mevcuttur ( Torres ve ark., 2019; Hasan Ali ve ark., 2019; Gönülol ve ark.,2018; Çelik ve ark., 2018; Ozakar ve ark., 2013; Çetin ve ark., 2013; Tal ve ark., 2017; Borgia ve ark., 2017; Pallesen ve Van Dijken, 2015a, 2015b; Stefanski ve Van Dijken, 2010; Demarco ve ark., 2009; Van Dijken ve ark., 2013; Van Dijken ve Pallesen, 2010; Van Dijken ve Hasselrot, 2010; Scotti ve ark., 2016; Marques ve ark., 2018; Boruzini- at ve ark., 2019; Tabassum ve ark., 2019). Yapılan restorasyonların takip süresine bakıldığında; en fazla 3 yıldan az takip süresi olan çalışmalar bulunmaktadır (Torres ve ark., 2019; Çakır ve Demirbuga, 2018; Tanner ve ark., 2018; Aljawad ve Rees, 2016; Veloso ve ark., 2018; Stefanski ve van Dijken, 2010; de Carvalho ve ark., 2015; Campagna ve ark., 2018; Çelik ve ark., 2018; Tal ve ark., 2017; Balkaya ve Arslan, 2020; Priyank ve ark., 2016; Serrano ve ark., 2013; Hasan Ali ve ark., 2019; McCracken ve ark.,2013; Friedl ve ark., 2011). 20-25 yll takip süresi aralığında ise en az sayıda çalışma yer almaktadır (Namgung ve ark., 2013; Da Rosa Rodolpho ve ark., 2011). Bu bilgilerle ilgili bilgi tablo 1'de sunulmuştur.

Tablo 1: Hasta sayısı, restorasyon sayısı, takip süresi ve yaş aralığı ile ilgili klinik çalışmalar

\begin{tabular}{|c|c|c|c|c|c|c|c|}
\hline Hasta Sayısı & Makale Sayısı? & Restorasyon Sayısı & Makale & $\begin{array}{c}\text { Takip Sü- } \\
\text { resi }\end{array}$ & Çalışma & $\begin{array}{c}\text { Yas } \\
\text { Aralı̆ı }\end{array}$ & Makale \\
\hline$<30$ & 7 & $<50$ & 3 & $<3$ yıl & 16 & $<18$ & 11 \\
\hline $30-50$ & 13 & $50-150$ & 19 & $3-5 \mathrm{yll}$ & 10 & $>18$ & 11 \\
\hline $50-100$ & 17 & $150-200$ & 10 & $5-15 \mathrm{yll}$ & 15 & $>25$ & 5 \\
\hline $100-150$ & 6 & $200-500$ & 11 & $15-20 \mathrm{yll}$ & 4 & $>35$ & 8 \\
\hline $150-250$ & 2 & $500-1000$ & 6 & $20-25 \mathrm{yll}$ & 2 & $>50$ & 7 \\
\hline $250-500$ & 7 & $1000-2000$ & 2 & $25-30 \mathrm{yll}$ & 3 & & \\
\hline $500-550$ & 1 & $2000-5000$ & 2 & & & & \\
\hline$>3000$ & 4 & $>5000$ & 4 & & & & \\
\hline
\end{tabular}

Bazı makalelerde çalışmaya başlamadan önce hastalar birtakım kriterlere göre değerlendirilerek çalışmaya dahil edilmemiștir. En fazla dikkate alınan ve hariç tutulan kriter hastaların tıbbi hikayesi (Balkaya ve Arslan, 2020; Torres ve ark., 2019; Marques ve ark., 2018; Frese ve ark., 2013; Diem ve ark., 2014; Pallesen ve Van Dijken, 2013; Al Samhan ve ark., 2010; Huth ve ark., 2011; Boing ve ark., 2018; Çelik ve ark., 2018; Montagner ve ark., 2018) olmuştur. Bunu periodontal hastalık varlığının (Balkaya ve
Arslan, 2020; Bresser ve ark., 2019; de Carvalho ve ark., 2015; Serrano ve ark., 2013; Van Dijken ve ark., 2013; Huth ve ark., 2011; Çelik ve ark., 2018; Diem ve ark., 2014; Çakır ve Demirbuga, 2018; Marques ve ark., 2018) takip ettiği görülmektedir. Plak skorunun $>\% 20$ olması (Scotti ve ark., 2015) bir makalede hariç tutulacak kriter olarak kabul edilmiștir. Klinik çalışmalarda hariç tutma kriterleri tablo 2'de sunulmuştur.

Tablo 2: Klinik çalışmalarda hariç tutma kriterleri

\begin{tabular}{|c|c|}
\hline Klinik Çalışma Hariç Tutma Kriterleri & Konuyla İlgili Çalışma Sayısı \\
\hline Periodontal Hastalık & 10 \\
\hline Hamile/Emziren & 4 \\
\hline Tıbbi Hikaye & 11 \\
\hline Zayıf Oral Hijyen & 6 \\
\hline Aproks/Karşı Kontak Yokluğu & 4 \\
\hline Plak Skoru>\%20 & 1 \\
\hline Kserostomi & 3 \\
\hline Parafonksiyonel Alışkanlık & 3 \\
\hline Bruksizm Varlığı & 3 \\
\hline Ortodontik Tedavi & 2 \\
\hline
\end{tabular}


Yapılan klinik çalıșmalarda ağırlıklı olarak posterior dișler ve vital olan dișler kullanılmakla birlikte anterior dişlerin yer aldığı on altı makale mevcuttur (Frese ve ark., 2013; Baldissera ve ark., 2013; Namgung ve ark., 2013; Serrano ve ark., 2013; McCracken ve ark., 2013; Van Dijken ve ark., 2010; Aljawad ve Rees, 2016; Lempel ve ark., 2017; Collares ve ark., 2017; Priyank ve ark., 2016; de Carvalho ve ark., 2016; Çelik ve ark., 2018; Tanner ve ark., 2018; Montagner ve ark., 2018; Boing ve ark., 2018; Kanzow ve Wiegand, 2019). Devital dişlerin kullanıldığı yirmi üç makale bulunmaktadır (Jiang ve ark., 2010; van de Sande ve ark., 2013; Czasch ve Illie, 2013; Ozcan ve Pekkan, 2013; Huang ve ark., 2011; El-safty S ve ark., 2012; Bauer ve ark., 2012; Illie ve ark., 2012; Misilli, 2016; Fronza ve ark., 2016; Ernesto ve ark., 2017; Boing ve ark., 2018; Scotti ve ark., 2015; Flury ve ark., 2014; Sripetchdanond ve ark., 2014; Hemadri ve ark., 2014; Belli ve ark., 2014; Bresser ve ark.,2019; Sud ve ark., 2019; Marques ve ark., 2018; Tanner ve ark., 2018; Ravasini ve ark., 2018; Kanzow ve Wiegand, 2019). Klinik çalışmalarda kullanılan dişlerle ilgili tüm bilgiler tablo 3 'de sunulmuştur.

Tablo 3: Klinik çalışmalarda kullanılan dișlerle ilgili veriler

\begin{tabular}{|c|c|}
\hline Klinik Çalışmalarda Kullanılan Diş Bilgileri & Çalışma Sayısı \\
\hline Anterior Dişler & 16 \\
\hline Posterior Dişler & 61 \\
\hline Vital Dişler & 34 \\
\hline Devital Dişler & 23 \\
\hline
\end{tabular}

Derlemedeki çalışmalarda genellikle direk teknik kullanılarak restoratif materyaller uygulanmıștır. İndirek/semidirek tekniğin uygulandığı on bir makale bulunmaktadır (Ravasini ve ark., 2018; Torres ve ark., 2019; Miura ve ark., 2018; da Veiga ve ark., 2016; Van Dijken ve ark., 2010; Jiang ve ark., 2010; Çetin ve ark., 2013; Ozakar ve ark., 2013; Huth ve ark., 2011; Shembish ve ark., 2015; Bresser ve ark.,
2019). Çok çeşitli restoratif materyallerin kullanıldığı görülmekle birlikte çalışmalarda farklı türlerde kompozit rezinler kullanılmıștır. En az kullanılan restoratif materyal ise kompomerdir (Van Dijken ve Pallesen, 2010; Maserejian ve ark., 2012; Mahn ve ark., 2015). Klinik çalıșmalarda kullanılan materyal ve tekniklerle ilgili veriler tablo 4 ve 5'de verilmiștir.

Tablo 4: Klinik çalışmalarda kullanılan materyal ve tekniklerle ilgili veriler

\begin{tabular}{|c|c|c|}
\hline Kullanılan Restoratif Materyal & İlgili Makale Sayısı & Direk/Indirek Teknik \\
\hline Kompozit & 63 & $47 / 11$ \\
\hline Akışkan Kompozit & 4 & \\
\hline Rezin Modifiye Cam İyonomer & 6 & \\
\hline Cam İyonomer & 10 & \\
\hline Porselen & 6 & \\
\hline Kompomer & 3 & \\
\hline Amalgam & 6 & \\
\hline
\end{tabular}

Tablo 5: Çalışmalarda kullanılan materyallerle ilgili ayrıntılı bilgi

\begin{tabular}{|c|c|c|c|c|}
\hline No & Kompozit Adı & Kullanıldığı Çalışma & Adeziv Sistem & $\begin{array}{c}\text { Diğer Restoratif } \\
\text { Materyal }\end{array}$ \\
\hline $1^{106}$ & $\begin{array}{c}\text { Tetric EvoFlow Bulk Fill, Tetric EvoC- } \\
\text { ream(Ivoclar Vivadent AG, Schaan, } \\
\text { Lichtenstein, Germany), Estelite } \\
\text { Equick(Tokuyama, Tokyo, Japan) }\end{array}$ & $\begin{array}{l}\text { Derin Marjin Elevasyo- } \\
\text { nu/IN Vivo }\end{array}$ & $\begin{array}{c}\text { \%35 Fosforik Asit (Ultradent } \\
\text { Ultra-etch, South Jordan, USA), } \\
\text { Optibond FL(Kerr, Bioggio, Swit- } \\
\text { zerland),\%4,9 Hidroflorik asit } \\
\text { (IPS Ceramic etching jel, Ivoclar } \\
\text { Vivadent) }\end{array}$ & Porselen \\
\hline $2^{105}$ & $\begin{array}{c}\text { GrandioSO(Voco GmbH, Cuxhaven, } \\
\text { Germany) }\end{array}$ & $\begin{array}{l}\text { Direk ve Semidirek Tek- } \\
\text { nik/ iN Vivo }\end{array}$ & $\begin{array}{c}\text { Futurabond U(Voco), Ceramic } \\
\text { Bond(Voco) }\end{array}$ & \\
\hline $3^{13}$ & Kompozit & $\begin{array}{c}\text { Servikal Restorasyonlar } \\
\text { Hakkında Retrospektif } \\
\text { Klinik Çalıșma/ iN Vivo }\end{array}$ & & Cís \\
\hline
\end{tabular}




\begin{tabular}{|c|c|c|c|c|}
\hline $4^{65}$ & $\begin{array}{c}\text { Filtek Z250(3M ESPE, Seefeld, Ger- } \\
\text { many), Filtek Silorane(3M ESPE, } \\
\text { Seefeld, Germany) }\end{array}$ & $\begin{array}{l}\text { Siloran/Metakrilat Kom- } \\
\text { pozit Rezin } 3 \text { Yıl Takibi/ } \\
\text { iN Vivo }\end{array}$ & $\begin{array}{l}\text { Clearfil Se Bond(Kuraray, Oka- } \\
\text { yama, Japan), Siloran Adeziv Sis- } \\
\text { tem(3M ESPE, Seefeld, Germany) }\end{array}$ & \\
\hline $5^{75}$ & $\begin{array}{l}\text { Estelite(Tokuyama, Japan), Z250(3M } \\
\text { ESPE, USA), Z100(3M ESPE, USA), } \\
\text { Synergy(Coltène/Whaledent Altstät- } \\
\text { ten, Switzerland), Clearfil Majesty } \\
\text { Posterior(Kuraray, Japan) }\end{array}$ & $\begin{array}{l}\text { Fiber Destekli Rezin } \\
\text { Kompozit 2,5 Yll Takip/ } \\
\text { iN VivO }\end{array}$ & $\begin{array}{c}\text { Vivapen(IvoclarVivadent, Schaan, } \\
\text { Liechtenstein), Clearfil Se Bond(- } \\
\text { Kuraray, Tokyo, Japan),Scotchbon- } \\
\text { d(3M ESPE, USA) }\end{array}$ & \\
\hline $6^{8}$ & $\begin{array}{c}\text { Tetric Ceram(Ivoclar Vivadent, Am- } \\
\text { herst, NY, USA), Sinfony(3M ESPE, } \\
\text { USA), Enamel Plus Hri(Micerium, } \\
\text { Avegna, Italy), Signum, Ceramis(He- } \\
\text { raeus Kulzer, Germany) }\end{array}$ & $\begin{array}{c}\text { İndirek Restorasyon } 20 \\
\text { Yll/IN VivO }\end{array}$ & $\begin{array}{l}3 \text { aşamalı teknik(Syntac, Ivoclar } \\
\text { Vivadent, Schaan, Liechtenstein) }\end{array}$ & \\
\hline $7^{139}$ & $\begin{array}{l}\text { Hibrit Veya Mikrohibrit Rezin Kom- } \\
\text { pozit }\end{array}$ & $\begin{array}{l}\text { Amalgam Kompozit Re- } \\
\text { view Çalışması }\end{array}$ & & $\begin{array}{l}\text { Yüksek Bakır İçerikli } \\
\text { Dağınık Faz Amalgam }\end{array}$ \\
\hline $8^{22}$ & $\begin{array}{l}\text { Venus Flow(Heraeus Kultzer, Ger- } \\
\text { many), Venus Diamond(Heraeus } \\
\text { Kultzer, Germany) }\end{array}$ & $\begin{array}{l}\text { Kanal Tedavili CII Resto- } \\
\text { rasyon Ömrü/ iN VivO }\end{array}$ & $\begin{array}{c}\text { All Bond 2(Bisco, Schaumburg, } \\
\text { II, USA) }\end{array}$ & \\
\hline $9^{14}$ & $\begin{array}{c}\text { Filtek Z250(3M ESPE, St.Paul, MN, } \\
\text { USA), Gradia(GC America, Inc., Alsip, } \\
\text { II, USA),Herkulite XR(Kerr, Orange, } \\
\text { CA, USA), Renew(Bisco Inc., Schaum- } \\
\text { burg, II, USA) }\end{array}$ & $\begin{array}{l}\text { Direk Kompozit } 10 \text { Yll } \\
\text { Değerlendirme/ iN Vivo }\end{array}$ & $\begin{array}{l}\text { \%37 Fosforik Asit(3M ESPE, } \\
\text { St.Paul, MN, USA), Adper Single } \\
\text { Bond(3M ESPE, St.Paul, USA) }\end{array}$ & \\
\hline $10^{131}$ & $\begin{array}{c}\text { Charisma(Heraeus Kultzer, Hanau, } \\
\text { Germany), Herculite XR(Kerr, Oran- } \\
\text { ge, CA, USA),Z100(3M ESPE, St.Paul, } \\
\text { MN, USA) }\end{array}$ & $\begin{array}{l}\text { Süt Dişinde Posterior } \\
\text { Restorasyon Ömrü/IN } \\
\text { VIVO }\end{array}$ & $\begin{array}{l}\text { \%37 Fosforik Asit(3M ESPE, } \\
\text { St.Paul, MN, USA), Adper Single } \\
\text { Bond(3M ESPE, St.Paul, USA) }\end{array}$ & RMCİS:Vitrofil \\
\hline $11^{132}$ & Kompozit & $\begin{array}{c}\text { Amelogenezis } \\
\text { Imperfekta/ in vivo }\end{array}$ & & Cis, Porselen \\
\hline $12^{4}$ & $\begin{array}{c}\text { Charisma(Heraeus Kulzer South } \\
\text { America Ltda., São Paulo, SP, Bra- } \\
\text { zil),Z100(3M ESPE, St.Paul, MN, } \\
\text { USA), Tetric Ceram(Ivoclar Vivadent, } \\
\text { Amherst, NY, USA) }\end{array}$ & $\begin{array}{l}\text { Hasta Risk Faktörleri/ } \\
\text { iN vivo }\end{array}$ & $\begin{array}{l}\text { \%37 Fosforik Asit,Scotchbond } \\
\text { Multi-Purpose Veya Single Bon- } \\
\text { d(3M ESPE, St.Paul, MN, USA) }\end{array}$ & \\
\hline $13^{71}$ & $\begin{array}{c}\text { Clearfilphoto Posterior(Kuraray, } \\
\text { Japan), AP-X(Kuraray,Ve Diğer Hibrit } \\
\text { Kompozitler }\end{array}$ & $\begin{array}{l}\text { Kompozit Amalgam Sur- } \\
\text { vival } 12 \text { yll/ IN VIVO }\end{array}$ & $\begin{array}{c}3 \text { Aşamalı Etch-And-Rinse adhe- } \\
\text { sive(Photobond/SA Primer, Kura- } \\
\text { ray, Osaka, Japan) }\end{array}$ & Dispersalloy Amalgam \\
\hline $14^{67}$ & $\begin{array}{c}\text { Visio-Molar X(3M ESPE, St.Paul, MN, } \\
\text { USA) }\end{array}$ & $\begin{array}{l}\text { Mikromorfolojik Sonuç } \\
29 \text { Yll/ iN VivO }\end{array}$ & $\begin{array}{c}\text { Asit Ve Universal Bond(3M ESPE, } \\
\text { St.Paul, MN, USA) }\end{array}$ & \\
\hline $15^{92}$ & $\begin{array}{c}\text { Filtek Z350(3M ESPE, St.Paul, MN, } \\
\text { USA), Filtek P60(3M ESPE), Helio- } \\
\text { molar(Ivoclar Vivadent Schaan, Lie- } \\
\text { chtenstein) }\end{array}$ & $\begin{array}{l}\text { Posterior Kompozit Ka- } \\
\text { lite ve Survival, 5-20 Yll/ } \\
\text { IN VIVO }\end{array}$ & 2 Veya 3 Aşamalı Etch-And-Rinse & \\
\hline $16^{7}$ & $\begin{array}{l}\text { Clearfil Posterior(Cavex, Haarlem, } \\
\text { The Netherlands), Adaptic II(John- } \\
\text { son\&Johnson Ltd., New Brunswich, } \\
\text { NY, USA), Oclusin(ICI Dental, PLC } \\
\text { Pharmaceuticals Div., Cheshire, UK) }\end{array}$ & $\begin{array}{c}\text { Randomize Kontrollü CII } \\
\text { Restorasyon } 27 \text { Yıl/ IN } \\
\text { VIVO }\end{array}$ & $\begin{array}{l}\text { Clearfil New Bond(Kuraray, Osa- } \\
\text { ka, Japan), Asit, Etanol\%99=Dry } \\
\text { Bonding }\end{array}$ & \\
\hline $17^{47}$ & $\begin{array}{l}\text { Miradapt(Johnson\&Johnson Ltd., } \\
\text { New Brunswich, NY, USA), P10(3M } \\
\text { ESPE, St.Paul, MN, USA), P30(3M } \\
\text { ESPE, St.Paul, MN, USA) }\end{array}$ & $\begin{array}{c}\text { Randomize Konvansiyo- } \\
\text { nel Kompozit } 30 \text { Yll / IN } \\
\text { VIVO }\end{array}$ & $\begin{array}{l}\text { Concise Enamel Bond(3M ESPE, } \\
\text { St.Paul, MN, USA), Scotchbon- } \\
\text { d(3M ESPE, St.Paul, MN, USA) }\end{array}$ & \\
\hline $18^{91}$ & $\begin{array}{c}\text { Charisma(Heraeus Kulzer, Hanau, } \\
\text { Germany), Herculite XR(Kerr, Oran- } \\
\text { ge, CA, USA), Z100(3M ESPE, St.Paul, } \\
\text { MN, USA) }\end{array}$ & $\begin{array}{l}\text { Universal Kompozit/ iN } \\
\text { VivO }\end{array}$ & $\begin{array}{l}\text { \%37 Fosforik Asit, Scotch Bond } \\
\text { Multi-Purposeor Single Bond(3M } \\
\text { ESPE, St.Paul, MN, USA) }\end{array}$ & \\
\hline $19^{30}$ & $\begin{array}{c}\text { Filtek Z350(3M ESPE, St.Paul, MN, } \\
\text { USA) }\end{array}$ & $\begin{array}{l}\text { Genç Daimi Diş CCR/ } \\
\text { SCR/ iN vivo }\end{array}$ & $\begin{array}{l}\text { \%37 Asit, Adper Single Bond(3M } \\
\text { ESPE, St.Paul, MN, USA) }\end{array}$ & Rmcis:Vitremer \\
\hline
\end{tabular}




\begin{tabular}{|c|c|c|c|c|}
\hline $20^{10}$ & $\begin{array}{c}\text { Filtek Z350(3M ESPE, St.Paul, MN, } \\
\text { USA) }\end{array}$ & $\begin{array}{c}\text { Sigara Kullananlarda } \\
\text { Çürüksüz Servikal Lez- } \\
\text { yonların } 1 \text { Yll Değerlen- } \\
\text { dirmesi / iN VIVO } \\
\end{array}$ & $\begin{array}{c}\text { \%37 Fosforik Asit(Condac 37, } \\
\text { FGM, Jounville, Brazil), Scotch- } \\
\text { bond(3M ESPE, St.Paul, MN, USA) }\end{array}$ & \\
\hline $21^{74}$ & $\begin{array}{l}\text { G-Anial(GC EUROPE), Z350(3M } \\
\text { ESPE, St.Paul, MN, USA) }\end{array}$ & $\begin{array}{l}\text { Snow Plow Tekniği/ iN } \\
\text { VivO }\end{array}$ & $\begin{array}{l}\text { \%35 Fosforik Asit(Ultradent } \\
\text { GmbH, Germany), Single Bon- } \\
\text { d(3M ESPE, USA) }\end{array}$ & $\begin{array}{l}\text { Akışkan:G-Anial Flow, } \\
\text { Z350 Flow }\end{array}$ \\
\hline $22^{66}$ & Kompozit & $\begin{array}{c}\text { Sekonder Çürük Gelişimi/ } \\
\text { iN vivo }\end{array}$ & & Amalgam \\
\hline $23^{97}$ & $\begin{array}{c}\text { Heliomolar(Ivoclar Vivadent Schaan, } \\
\text { Liechtenstein) }\end{array}$ & CI Kavite Aşınma/ iN vivo & Selektif Etch & \\
\hline $24^{111}$ & $\begin{array}{c}\text { Lava Ultimate(Meisinger, Centennial, } \\
\text { CO, USA), Filtek Z100(3M ESPE, St. } \\
\text { Paul, MN, USA) }\end{array}$ & $\begin{array}{l}\text { CADCAM Yorulma Diren- } \\
\text { ci/ iN ViTRO }\end{array}$ & $\begin{array}{c}\text { Scotchbond(3M ESPE), RelyX } \\
\text { Ultimate(3M ESPE), Multilink } \\
\text { Automix System(Ivoclar Vivadent, } \\
\text { Schaan, Liechtenstein) }\end{array}$ & Porselen \\
\hline $25^{57}$ & $\begin{array}{l}\text { Gradia Direct Posterior(GC Avrupa, } \\
\text { Tokyo, Japan) }\end{array}$ & $\begin{array}{l}\text { Farklı Yerlesstirme Tek- } \\
\text { niklerinin Mikrosızıntı } \\
\text { Ölçümü/ iN viTRO }\end{array}$ & $\begin{array}{l}\text { Asit, Adper Single Bond 2(3M } \\
\text { ESPE, St.Paul, MN, USA) }\end{array}$ & \\
\hline $26^{15}$ & Kompozit & $\begin{array}{l}\text { Başarısızlık Sebepleri } 8 \\
\text { Yıl/ IN VIVO }\end{array}$ & $\begin{array}{c}2 \text { Assamalı Etch-And-Rinse, Adper } \\
\text { Single Bond 2(3M ESPE, St.Paul, } \\
\text { MN, USA) }\end{array}$ & \\
\hline $27^{127}$ & - & CII YVCÍS 6 Yll/ in Vivo & & $\begin{array}{l}\text { Fuji IX GP (GC Corpo- } \\
\text { ration, Tokyo, Japan), } \\
\text { Poly-acrylic Acid Condi- } \\
\text { tioner, Fuji LC Varnish }\end{array}$ \\
\hline $28^{11}$ & Kompozit & $\begin{array}{l}24 \text { Ay Kompozit Amal- } \\
\text { gam / IN VivO }\end{array}$ & & Amalgam \\
\hline $29^{16}$ & $\begin{array}{c}\text { P-50 APC(3M ESPE, St.Paul, MN, } \\
\text { USA), Herculite XR(Kerr, Orange, CA, } \\
\text { USA) }\end{array}$ & $\begin{array}{l}22 \text { Yll } 2 \text { Kompozit Değer- } \\
\text { lendirmesi/ in Vivo }\end{array}$ & $\begin{array}{l}\text { \%35 Fosforik Asit, Scotchbond } \\
\text { 2(3M ESPE), XRPrime/XR Bon- } \\
\text { d(Kerr) }\end{array}$ & \\
\hline $30^{18}$ & Kompozit & $\begin{array}{l}\text { İnley Onley Stres Dağıll- } \\
\text { mi/ IN ViTRO }\end{array}$ & & Porselen, Altın Alaşım \\
\hline $31^{23}$ & $\begin{array}{c}\text { Filtek Supreme Ultra(3M ESPE, St. } \\
\text { Paul, MN, USA) }\end{array}$ & $\begin{array}{l}\text { Universal Adeziv } 6 \text { ay/ } \\
\text { IN VIVO }\end{array}$ & $\begin{array}{c}\text { Scotchbond Universal(3M ESPE, } \\
\text { St.Paul, MN, USA) }\end{array}$ & \\
\hline $32^{27}$ & Kompozit Yok & $\begin{array}{c}\text { Servikal Restorasyonlar- } \\
\text { da Bonding Etkisi Me- } \\
\text { ta-Analiz }\end{array}$ & $\begin{array}{l}\text { Tek Ve2 Aşamalı Self-Etch Sistem- } \\
\text { ler,2 Ve } 3 \text { Assamalı Etch-And-Rinse } \\
\text { Sistemleri }\end{array}$ & RMCİS, CİS, Kompomer \\
\hline $33^{29}$ & $\begin{array}{c}\text { Heliomolar(Ivoclar Vivadent Schaan, } \\
\text { Liechtenstein) }\end{array}$ & $\begin{array}{l}\text { Kuveyt Üniversitesi Öğ- } \\
\text { rencileri } 3 \text { Yll/ iN VivO }\end{array}$ & $\begin{array}{l}\text { Optibond Solo Plus(Kerr, Orange, } \\
\text { CA, USA), Ultra Etch(Ultradent } \\
\text { Inc., South Jordan, Utah, USA) }\end{array}$ & \\
\hline $34^{5}$ & $\begin{array}{l}\text { Herculite(Heraeus Kulzer, Germany), } \\
\text { Spectrum(DeTrey Dentsply) }\end{array}$ & $\begin{array}{c}8 \text { Yll Değiștirme Nedenle- } \\
\text { ri/ IN VIVO }\end{array}$ & $\begin{array}{l}\text { Prime And Bond(DeTrey } \\
\text { Dentsply), Scotchbond MP(3M } \\
\text { ESPE, Germany), \%35 Fosforik } \\
\text { Asit, Concise Enamel Bond(3M } \\
\text { ESPE) }\end{array}$ & \\
\hline $35^{78}$ & $\begin{array}{c}\text { Filtek Supreme XT(3M ESPE, USA), } \\
\text { Enamel Plus HFO(Micerium, Avegna, } \\
\text { Italy) }\end{array}$ & $\begin{array}{l}\text { Kırık ve Diestema Kapa- } \\
\text { ma } 7 \text { Yll/ iN Vivo }\end{array}$ & $\begin{array}{l}\text { Ultra Etch(Ultradent GmbH, Ger- } \\
\text { many), Adper Single Bond(3M } \\
\text { ESPE, St.Paul, MN, USA) }\end{array}$ & \\
\hline $36^{93}$ & Mikrofil Ve Nanohibrit Kompozit & $\begin{array}{l}\text { Mikrofil Ve Nanohibrit } \\
\text { CII/ iN VivO }\end{array}$ & Tek Așamalı Self-Etch & \\
\hline $37^{99}$ & $\begin{array}{l}\text { Valux Plus(3M ESPE);Tescera Bod- } \\
\text { y(Bisco, Schaumburg, IL, USA), Bril- } \\
\text { liant Esthetic Line(Coltène/Whale- } \\
\text { dent AG, Altstãtten, Switzerland) }\end{array}$ & $\begin{array}{c}2 \text { İndirek Kompozitin } 3 \text { Yll } \\
\text { Takibi/ I } N \text { VIVO }\end{array}$ & $\begin{array}{l}\text { Adper Single Bond(3M ESPE, } \\
\text { St.Paul, MN, USA), One Step Plus(- } \\
\text { Bisco, Schaumburg, IL, USA) }\end{array}$ & \\
\hline $38^{100}$ & $\begin{array}{c}\text { Artglass, Charisma((Heraeus Kultzer, } \\
\text { Hanau, Germany) }\end{array}$ & $\begin{array}{c}4 \text { Yll Indirek Rezin İnley/ } \\
\text { INN VIVO }\end{array}$ & $\begin{array}{l}\text { Solid Bond((Heraeus Kultzer, } \\
\text { Hanau, Germany) }\end{array}$ & \\
\hline $39^{123}$ & Kompozit Yok & CíS Kohort/ in vivo & & $\begin{array}{l}\text { Fuji Ix Gp Extra, Equia(- } \\
\text { GC Avrupa, Tokyo, Ja- } \\
\text { pan) }\end{array}$ \\
\hline $40^{124}$ & G-Aenial(GC Avrupa, Tokyo, Japan) & $\begin{array}{l}\text { YVCIS NNCL } 2 \text { Yil/ IN } \\
\text { VIVO }\end{array}$ & $\begin{array}{c}\text { Optibond FL(KerrHawe SA, Biog- } \\
\text { gio, Switzerland), EQUIA Coat(GC } \\
\text { Avrupa, Tokyo, Japan) }\end{array}$ & $\begin{array}{l}\text { Equia(GC Avrupa, Tokyo, } \\
\text { Japan) }\end{array}$ \\
\hline
\end{tabular}




\begin{tabular}{|c|c|c|c|c|}
\hline $41^{120}$ & - & $\begin{array}{l}\text { Cam Karbomer Siman/ } \\
\text { iN ViTRO }\end{array}$ & $\begin{array}{c}\text { Equia Coat(GC Avrupa, Tokyo, } \\
\text { Japan) }\end{array}$ & $\begin{array}{c}\text { Fuji II LC(GC Avrupa } \\
\text { N.V., Leuven, Belgium), } \\
\text { Photac Fil Qouick Apli- } \\
\text { cap(3M ESPE, Seefeld, } \\
\text { Germany), GCP Glass Fil } \\
\text { and Gloss(GCP Dental, } \\
\text { Vianen, the Netherlands) }\end{array}$ \\
\hline $43^{129}$ & $\begin{array}{c}\text { Charisma Smart(Heraeus Kulzer, Ha- } \\
\text { nau, Germany), Filtek Bulk Fill(3M } \\
\text { ESPE, St.Paul, MN, USA) }\end{array}$ & $\begin{array}{l}3 \text { Farklı Materyal CII } \\
\text { Kavite, } 1 \text { Yıl/ İN VIVO }\end{array}$ & $\begin{array}{c}\text { Single Bond Universal(3M ESPE, } \\
\text { Neuss, Germany) }\end{array}$ & $\begin{array}{l}\text { Equia Forte Fil(GC, Tok- } \\
\text { yo, Japan) }\end{array}$ \\
\hline
\end{tabular}

Diş hekimlerinin restorasyonda kullandığı bu materyaller ağız ortamında birçok faktörden etkilenir ve bu durum ilerleyen zamanlarda materyallerin fiziksel, mekanik ve kimyasal özelliklerinin değişmesi olarak karşımıza çıkar. Bu çalışma için derlenen tüm klinik çalışmaların değerlendirilmesinde kullanılan farklı klinik değerlendirme kriterleri ve bu kriterler kullanılarak elde edilen verilerin istatistiği için kullanılan analizler de kayıt altına alınmıştır. Retrospektif çalışmalarda çeşitli site ve veri tabanları üzerinden bilgi edinilip yararlanılmıștır ve elde edilen bulgular istatiksel olarak çeşitli yöntem/testler ile değerlendirilmiştir. Kullanılan parametrelerle ilgili veriler Tablo 6'da sunulmuştur.

Tablo 6: Klinik çalışma değerlendirme kriterleri ve verilerin analizi için kullanılan istatistiki analizler

\begin{tabular}{|l|l|}
\hline \multicolumn{1}{|c|}{ Klinik Çalışma Değerlendirme Kriterleri } & Kaplan Meier \\
\hline USPHS & Log-Rank \\
\hline FDI & Ki Kare \\
\hline PICO & ANOVA \\
\hline O'Leary Plak Kontrol İndexi & CPM İndexi \\
\hline Turesky Plak İndexi & Mann Whitney U \\
\hline Ryge Kriterleri & Cox Regresyon Analizi \\
\hline Stroop Color-Word İnterference Test & Mcnemar Testi \\
\hline Letter Fluency Testi,WISC-III,WIAT & Consort \\
\hline Fotoğrafik Ve Mikromorfolojik Kodlama Endeksi & Friedman \\
\hline Gingival Kanama İndexi & Fisher İstatiksel Analizi \\
\hline DMFT & I $^{2}$ İndexi \\
\hline Angle insizal ilişkisi & Kruskal-Wallis Testi \\
\hline & Kolmogorov-Smirnov Testi \\
\hline Review kaynakları & Cohen'in Kappa Katsayısı \\
\hline PubMed & Olabilirlik Oran Testi \\
\hline LILACS,BBO,NOS(Newcastle Ottowa Scala) & T Testi \\
\hline Cochrane Kütüphanesi & Çapraz Tablolama \\
\hline Excerpta Medica Veritabanı & Wilcoxon Testleri \\
\hline Embase & Magno Et. All. Meta Analiz \\
\hline Scopus & Breslow Testi \\
\hline Web of Science & \\
\hline
\end{tabular}

Klinik değerlendirme yapılırken genellikle USPHS kriterleri kullanılmıștır. USPHS kriterleri tablo 7 de sunulmuştur.

USPHS kriterleri ile birlikte ya da tek başına FDI kriterlerine (Torres ve ark., 2019; Çakır ve Demirbuga, 2018; van de Sande ve ark., 2013; Baldissera ve ark.,
2013; Mena Serrano ve ark., 2013; Da Rosa Rodolpho ve ark., 2011) ve Ryge kriterlerine (Borgia ve ark., 2017; Yazıcı ve ark., 2010; Heintze ve Rousson, 2012; Priyank ve ark., 2016) göre değerlendirme yapan makaleler yer almaktadır. FDI kriterleri ile Ryge kriterlerine ait tablo 8 ve 9 'da verilmiştir. 
Tablo 7: USPHS kriterleri

\begin{tabular}{|c|c|c|c|c|}
\hline Skor & Alfa & Bravo & Charlie & Delta \\
\hline $\begin{array}{l}\text { Diş Renginin Stabi- } \\
\text { litesi }\end{array}$ & $\begin{array}{l}\text { Değişim } \\
\text { Yok }\end{array}$ & $\begin{array}{l}\text { 2haftalık Takipte } 4 \\
\text { Tona Kadar Değişim }\end{array}$ & $\begin{array}{c}\text { 2haftalık Takipte } 8 \text { Tona Kadar } \\
\text { Değişim }\end{array}$ & $\begin{array}{l}\text { 2haftalık Takipte }>8 \\
\text { Ton Değişim }\end{array}$ \\
\hline Yüzey Pürüzlülüğü & Sağlam & Pürüzlü & & \\
\hline Anatomik Form & Sağlam & $\begin{array}{l}\text { Yüzeysel Hafif Madde } \\
\text { Kaybı(Așınma,Yarık) }\end{array}$ & $\begin{array}{l}\text { Derin Fazla Madde Kaybı(Aşınma,- } \\
\text { Yarık) }\end{array}$ & $\begin{array}{l}\text { Parsiyel/Total Yapı } \\
\text { Kaybı }\end{array}$ \\
\hline $\begin{array}{l}\text { Marjinal Bütün- } \\
\text { lük(Mine) }\end{array}$ & Sağlam & $\begin{array}{l}\text { Pozitif Basamak,Poli- } \\
\text { sajla Kaldırılabilir }\end{array}$ & $\begin{array}{l}\text { Hafif Negatif Basamak,Kaldırıla- } \\
\text { maz,Lokalize }\end{array}$ & $\begin{array}{c}\text { Marjinin Büyük } \\
\text { Bölümünde Güçlü } \\
\text { Negatif Basamak,Kal- } \\
\text { dırılamaz }\end{array}$ \\
\hline$\underset{\text { ğişimi }}{\text { Marjinal Renk De- }}$ & Yok & $\begin{array}{l}\text { Hafif Renk Değişimi,Po- } \\
\text { lisajla Kaldırılabilir }\end{array}$ & $\begin{array}{l}\text { Lokalize Renk Değişimi,Kaldırıla- } \\
\text { maz }\end{array}$ & $\begin{array}{c}\text { Marjinin Büyük } \\
\text { Bölümünde Güçlü } \\
\text { Renk Değişimi,Kaldı- } \\
\text { rlla-Maz }\end{array}$ \\
\hline Sekonder Çürükler & Yok & Çürük Mevcut & & \\
\hline $\begin{array}{c}\text { Gingival } \\
\text { Inflamasyon }\end{array}$ & Yok & Hafif & Orta & Şiddetli \\
\hline $\begin{array}{l}\text { Restorasyon Renk } \\
\text { Stabilitesi }\end{array}$ & $\begin{array}{l}\text { Değişim } \\
\text { Yok }\end{array}$ & $\begin{array}{l}\text { Temel Durumla Kar- } \\
\text { şllaştırıldığında Renk } \\
\text { Değişimi Mevcut }\end{array}$ & & \\
\hline
\end{tabular}

Tablo 8: FDI kriterleri

\begin{tabular}{|c|c|c|c|c|c|}
\hline Siniflama & Estetik Nitelik & \multicolumn{2}{|c|}{ Fonksiyonel Nitelikler } & \multicolumn{2}{|c|}{ Biyolojik Nitelikler } \\
\hline Klinik Olarak & $\begin{array}{c}\text { 1. Marjin } \\
\text { Renklenmesi }\end{array}$ & $\begin{array}{l}\text { 2. Kırıklar Ve } \\
\text { Retansiyon }\end{array}$ & $\begin{array}{l}\text { 3. Marjinal } \\
\text { Adaptasyon }\end{array}$ & $\begin{array}{l}\text { 4. Postop(Hiper) } \\
\text { Hassasiyet }\end{array}$ & 5. Çürük Tekrarı \\
\hline A. Çok İyi & Yok & $\begin{array}{c}\text { Restorasyon } \\
\text { Korunmuş, Kırık/ } \\
\text { Çatlak Yok }\end{array}$ & $\begin{array}{l}\text { Uyumlu Ana- } \\
\text { hat,Aralık Yok }\end{array}$ & Yok & $\begin{array}{l}\text { Primer/Sekonder } \\
\text { Çürük Yok }\end{array}$ \\
\hline $\begin{array}{l}\text { B.Klinik Olarak } \\
\text { İyi(Düzeltmeden } \\
\text { Sonra Çok İyi) }\end{array}$ & $\begin{array}{l}\text { Minor Marjinal } \\
\text { Renklenme, } \\
\text { Polisajla Kolayca } \\
\text { Kaldırılır. }\end{array}$ & $\begin{array}{l}\text { Küçük İnce Çizgi } \\
\text { Şeklinde Çatlak }\end{array}$ & $\begin{array}{c}\text { Marjinal Aralık } \\
(50 \mu \mathrm{m}), \text { Polisaj- } \\
\text { la Kaldırılabilir } \\
\text { Küçük Marjinal } \\
\text { Kırık }\end{array}$ & $\begin{array}{l}\text { Sınırlı Süre Hafif } \\
\text { Hassasiyet }\end{array}$ & $\begin{array}{l}\text { Çok Küçük } \\
\text { Lokalize Demine- } \\
\text { ralizasyon, Tedavi } \\
\text { Gerekmez }\end{array}$ \\
\hline \multirow[t]{2}{*}{$\begin{array}{l}\text { C.Yeterli/Tat-Min } \\
\text { Edici(Yan Etkisi } \\
\text { Olmayan Küçük } \\
\text { Eksiklikler Fakat } \\
\text { Dişe Zarar } \\
\text { Vermeden Ayarla- } \\
\text { nabilir) }\end{array}$} & $\begin{array}{c}\text { Orta Marjinal } \\
\text { Renklenme, Este- } \\
\text { tik Olarak Kabul } \\
\text { Edilemez. }\end{array}$ & $\begin{array}{c}\text { A) +2 Veya Geniş } \\
\text { Çizgi Yarlklar Ve/ } \\
\text { Veya }\end{array}$ & $\begin{array}{c}\text { A) 1ara- } \\
\text { lık< } 150 \mu \mathrm{m}, \text { Kald }{ }^{-}- \\
\text {rllamaz. }\end{array}$ & $\begin{array}{c}\text { A) Erken/Daha } \\
\text { Yoğun }\end{array}$ & $\begin{array}{c}\text { Geniş Demin. } \\
\text { Bölgeleri, Ama } \\
\text { Sadece Koruyucu } \\
\text { Önlemler Gerekli }\end{array}$ \\
\hline & & $\begin{array}{l}\text { B) Chipping(Mar- } \\
\text { jinal Bütünlügü } \\
\text { Etkilemez) }\end{array}$ & $\begin{array}{l}\text { B) Şiddetli Küçük } \\
\text { Mine/Dentin } \\
\text { Kırıkları }\end{array}$ & $\begin{array}{l}\text { B) Gecikmeli/Za- } \\
\text { yıf Hassasiyet;Öz- } \\
\text { nel Șikayet Yok, } \\
\text { Tedavi Gerekmez }\end{array}$ & \\
\hline \multirow[t]{2}{*}{$\begin{array}{l}\text { D.Tatmin Etme- } \\
\text { yen (Tamir veya } \\
\text { Proflaktik Sebep- } \\
\text { ler) }\end{array}$} & $\begin{array}{l}\text { Belirgin Marji- } \\
\text { nal Renklenme; } \\
\text { İyileşme İçin } \\
\text { Major Müdahale } \\
\text { Gerekli. }\end{array}$ & $\begin{array}{l}\text { Marjinal Kaviteye } \\
\text { Zarar VerenChip- } \\
\text { ping Kırıkları; } \\
\text { Parsiyel Kayıplı/ } \\
\text { Sız Bulk Kırık- } \\
\text { lar(Restorasyon } \\
\text { Yarısından Az) }\end{array}$ & $\begin{array}{l}\text { A)Aralık>250 } \mu \mathrm{m}- \\
\text { Veya Dentin/ } \\
\text { Taban Expozu }\end{array}$ & $\begin{array}{l}\text { A) Erken/Çok } \\
\text { Yoğun }\end{array}$ & $\begin{array}{l}\text { Kavitasyonlu } \\
\text { Çürükler(Lokali- } \\
\text { Ze ve Ulaşllabilir, } \\
\text { Tamir Edilebilir.) }\end{array}$ \\
\hline & & & $\begin{array}{l}\text { B)Marjine Za- } \\
\text { rar Veren Chip } \\
\text { Kırıkları }\end{array}$ & $\begin{array}{c}\text { B)Gecikmeli/ } \\
\text { Zayıf Öznel } \\
\text { Şikayetle Birlikte }\end{array}$ & \\
\hline
\end{tabular}




\begin{tabular}{|c|c|c|c|c|c|}
\hline & & & & $\begin{array}{l}\text { C) Negatif Hassa- } \\
\text { siyet Müdahale } \\
\text { Gerekli Ama } \\
\text { Yenileme Değil }\end{array}$ & \\
\hline $\begin{array}{c}\text { E. Zayıf (Yenileme } \\
\text { Gerekli) }\end{array}$ & $\begin{array}{l}\text { Derin Marjinal } \\
\text { Renklenme, } \\
\text { Müdahale İçin } \\
\text { Ulaşılamaz. }\end{array}$ & $\begin{array}{c}\text { (Parsiyel/Tam) } \\
\text { Restorasyon } \\
\text { Kaybı }\end{array}$ & $\begin{array}{c}\text { Dolgu Hareketli } \\
\text { Ama Yerinde }\end{array}$ & $\begin{array}{c}\text { Çok Yoğun,Akut } \\
\text { Pulpitis/Devital. } \\
\text { Endodontik Teda- } \\
\text { vi Ve Restorasyon } \\
\text { Gerekli }\end{array}$ & $\begin{array}{l}\text { Derin Sekonder } \\
\text { Çürük/Expoz } \\
\text { Dentin Tamir İçin } \\
\text { Ulaşllamaz }\end{array}$ \\
\hline
\end{tabular}

Tablo 9: Ryge kriterleri

\begin{tabular}{|c|c|c|c|}
\hline KATEGORİ & + & - & KLİNİK DEĞERLENDİRME KRİTERLERİ \\
\hline \multirow{3}{*}{ Anatomik Form } & 0 & & Restorasyon Diş Anatomisine Uyumlu \\
\hline & & 2 & $\begin{array}{l}\text { Eksik Konturlu, Dentin Ya Da Kaide Açıkta, Kontak Hatalı, Kendi Kendine } \\
\text { Düzelemez, Okluzal Yükseklik Azalmış, Okluzal Etkilenmiş }\end{array}$ \\
\hline & & 3 & $\begin{array}{l}\text { Restorasyon Eksik Ya Da Travmatik Okluzyon, Restorasyon Diște Ya Da } \\
\text { Komșu Dokularda Ağriya Sebep Oluyor }\end{array}$ \\
\hline \multirow{5}{*}{$\begin{array}{l}\text { Marjinal } \\
\text { Adaptasyon }\end{array}$} & 0 & & Restorasyon Mevcut Anatomik Forma Uygun, Sond Takılmıyor \\
\hline & 1 & & Sond Takılıyor Ancak Sondun Gidebileceği Kadar Açıklık Yok \\
\hline & 2 & & Marjinde Mine Açıkta \\
\hline & & 3 & Marjinde Bariz Açıklık Var; Dentin Ve Kaide Açıkta \\
\hline & & 4 & Restorasyon Mobil, Kırık Ya Da Eksik \\
\hline \multirow{5}{*}{ Renk Uyumu } & 0 & & Çok İyi \\
\hline & 1 & & İyi \\
\hline & 2 & & Hafif Değişiklik Var, Gölge/Translusensi Var \\
\hline & & 3 & Bariz Değişiklik Var \\
\hline & & 4 & Renk Çok Fazla Değişmiş \\
\hline \multirow{4}{*}{$\begin{array}{c}\text { Marjinal } \\
\text { Renklenme }\end{array}$} & 0 & & Renklenme Yok \\
\hline & 1 & & Hafif Boyanmış, Cila İle Uzaklaştırılabilir \\
\hline & 2 & & Bariz Boyanma, Cila İle Uzaklaştırılmaz \\
\hline & & 3 & Çok Boyanmış \\
\hline \multirow{2}{*}{$\begin{array}{l}\text { Sekonder } \\
\text { Çürük }\end{array}$} & 0 & & Restorasyon Marjininde Çürük Belirtisi Yok \\
\hline & & 1 & Marjin Boyunca Çürük Mevcut \\
\hline \multirow{4}{*}{$\begin{array}{l}\text { Yüzey } \\
\text { Pürüzlülüğü }\end{array}$} & 0 & & Düzgün Yüzey \\
\hline & 1 & & Hafif Düzensiz Ve Pürüzlü Yüzey \\
\hline & 2 & & Pürüzlü Yüzey, Tekrar Düzeltilemez \\
\hline & & 3 & Yüzeyde Derin Çentikler Ve Düzensiz Oluklar Mevcut \\
\hline
\end{tabular}




\section{SONUÇ}

Günümüzde kompozit rezinler hakkında yapılan çalıșmaların amacı kompozit rezin restorasyonların başarısızlıklarına dair sebepleri ve çözümlerini araştırarak kompozit rezinleri ideal restoratif materyal haline getirmektir. Kompozit, teknolojiye uyumlu șekilde sürekli geliștirilen restoratif materyallerin gelecek neslini temsil etmektedir.

$\mathrm{Bu}$ derlemenin sonuçlarına göre; literatürdeki çalışmaların değerlendirilmesinden posterior ve anterior dişlerde kompozit rezin restorasyonların olumlu performans gösterdiği gösterilmiştir. Anterior kompozit rezin restorasyonların başarısızlık oranları posterior dișlerdeki kompozit rezin restorasyonlardan daha düşüktür.

Kompozit restorasyonların uzun ömürlülüğü, uygulama basamakları / diş hekimi tecrübesi, hasta ve diş / restorasyon arasındaki çeşitli faktörlerden etkilenmektedir. Çeşitli parametreler kullanılarak yapılan çalışmaların derlemesi ve kabul edilen pek çok araştırmanın sonucu bize restoratif materyal seçiminin ve restoratif prosedürlerin ne kadar önemli olduğunu göstermektedir. Bununla birlikte restorasyonun ömrü ve ağızda kalma süresinde hastaların oral hijyen alışkanlıklarının temel etken olduğu göz ardı edilmemelidir.

Hastayla ilişkili spesifik risk faktörlerinin klinik olarak değerlendirilmesi ve standardizasyonu zordur. Kompozit rezin restorasyonların ömrü açısından, hastaların oral hijyen derecesini kontrol ederek hastaları teşvik etmek ve oral hijyen hakkında bilgilendirmek büyük önem arz etmektedir. Ayrıca restorasyona dair erken dönemde görülen başarısızlıklarla ilgili risk faktörleri ve etkenleri tanıyı belirleyebilirsek hastalara daha etkili tedavi planları önerebilir, muhtemel başarısızlık ve olumsuzlukları önleme imkanı bulabiliriz. Düzenli kontroller ile olası bașarısızlıklar başlangıç seviyesinde onarılabilir ve restorasyonun idamesi sağlanabilir. Kompozit rezin restorasyonların önünde aşılması gereken en önemli zorluğun uygulama basamaklarındaki teknik hassasiyet olduğu görülmektedir.

Kompozit rezinlerin tamir edilebilir özelliğe sahip olması en önemli avantajı olarak ön plana çıkmaktadır. Kompozit rezin restorasyonların klinik ömrünü artırıcı çalışmalara ihtiyaç vardır.

\section{KAYNAKLAR}

1. Sunnegårdh-Grönberg $\mathrm{K}$, van Dijken JW, Funegård U, Lindberg A, Nilsson M. Selection of dental materials and longevity of replaced restorations in Public Dental Health clinics in northern Sweden. J Dent. 2009 Sep;37:673-8.

2. Heintze SD, Rousson V. Clinical effectiveness of dire- ct class II restorations- a meta analysis. The J Adhes Dent 2012;14:407-31.

3. Correa MB, Peres MA, Peres KG, Horta BL, Barros $\mathrm{AD}$, Demarco FF. Do socieconomic determinants affect the quality of posterior dental restorations? A multilevel approach. J Dent 2013; 41: 960-967.

4. Van de Sande FF, Opdam NJ, Da Rosa Rodolpho PA, Correa MB, Demarco FF, Cenci MS. Patient risk factors' influence on survival of posterior composites. J Dent Res 2013; 92: 78-83.

5. Pallesen U, van Dijken JWV, Halken J, Hallonsten A.L, Höigaard R. Longevity of posterior resin composite restorations in permanent teeth in Public Dental Health Service: a prospective 8 years follow up. J Dent 2013; 41: 297-306.

6. Demarco FF, Correa MB, Cenci MS, Moraes RR, Opdam NJ. Longevity of posterior composite restorations: not only a matter of materials. Dent Mater 2012; 28: 87-101.

7. Pallesen U, JWV van Dijken. A randomized controlled 27 years follow up of three resin composites in class II restorations. J Dent 2015; 43: 1547-58.

8. Ravasini F, Bellussi D, Pedrazzoni M, Ravasini T, Orlandini P, Meleti M, et al. Treatment Outcome of Posterior Composite Indirect Restorations: A Retrospective 20Year Analysis of 525 Cases with a Mean Follow-up of 87 Months. Int J Periodontics Restorative Dent. 2018 Sep/Oct;38:655-663.

9. Kadzaeva ZS, Turkina AY, Doroshina VY. Otdalennye rezul'taty restavratsii zubov kompozitnymi materialami svetovogo otverzhdeniia: obzor literatury [The long-term results of teeth restoration with composite resin materials: a systematic literature review]. Stomatologiia (Mosk). 2019;98:117-122.

10. de Carvalho LD, Gondo R, Lopes GC. One-year Clinical Evaluation of Resin Composite Restorations of Noncarious Cervical Lesions in Smokers. J Adhes Dent. 2015 Aug;17:405-11.

11. McCracken MS, Gordan VV, Litaker MS, Funkhouser E, Fellows JL, Shamp DG, et al. A 24-month evaluation of amalgam and resin-based composite restorations: Findings from The National Dental Practice-Based Research Network. J Am Dent Assoc. 2013 Jun;144:58393.

12. Laske M, Opdam NJ, Bronkhorst EM, Braspenning JC, Huysmans MC. Longevity of direct restorations in Dutch dental practices. Descriptive study out of a practice based research network. J Dent. 2016 Mar;46:12-7.

13. Namgung C, Rho YJ, Jin BH, Lim BS, Cho BH. A retrospective clinical study of cervical restorations: longevity and failure-prognostic variables. Oper Dent. 2013 Jul-Aug;38:376-85.

14. Lempel E, Tóth Á, Fábián T, Krajczár K, Szalma J. Retrospective evaluation of posterior direct composite restorations: 10-year findings. Dent Mater. 2015 Feb;31:115-22.

15. Montagner AF, Sande FHV, Müller C, Cenci MS, Susin AH. Survival, reasons for failure and clinical characteristics of anterior/posterior composites: 8-year findings. Braz Dent J. 2018 Nov-Dec;29:547-554.

16. Da Rosa Rodolpho PA, Donassollo TA, Cenci MS, Loguércio AD, Moraes RR, Bronkhorst EM, et al. 22-Year clinical evaluation of the performance of two poste- 
rior composites with different filler characteristics. Dent Mater. 2011 Oct; 27:955-63.

17. Campagna P, Pinto LT, Lenzi TL, Ardenghi TM, de Oliveira Rocha R, Oliveira MDM. Survival and associated risk factors of composite restorations in children with early childhood caries: A clinical retrospective study. Pediatr Dent. 2018 May 15;40:210-214.

18. Jiang W, Bo H, Yongchun G, LongXing N. Stress distribution in molars restored with inlays or onlays with or without endodontic treatment: a three-dimensional finite element analysis. J Prosthet Dent. 2010 Jan;103:6-12.

19. Scotti N, Scansetti M, Rota R, Pera F, Pasqualini D, Berutti $\mathrm{E}$. The effect of the post length and cusp coverage on the cycling and static load of endodontically treated maxillary premolars. Clin Oral Investig. 2011 Dec;15:923-9.

20. Kanzow P, Wiegand A. Retrospective analysis on the repair vs. replacement of composite restorations. Dent Mater. 2020 Jan;36:108-118.

21. Dayangaç GB. Kompozit Rezin Restorasyonlar. 1. Baskl, Ankara: Güneş Kitabevi Ltd. Şti. 2000. Sayfa 89.

22. Scotti N, Eruli C, Comba A, Paolino DS, Alovisi M, Pasqualini D, et al. Longevity of class 2 direct restorations in root-filled teeth: A retrospective clinical study. J Dent. 2015 May;43:499-505.

23. Mena-Serrano A, Kose C, De Paula EA, Tay LY, Reis A, Loguercio AD, et al. A new universal simplified adhesive: 6-month clinical evaluation. J Esthet Restor Dent. 2013 Feb;25:55-69.

24. De Munck J, Van Landuyt K, Peumans M, Poitevin A, Lambrechts P, Braem M, et al. A critical review of the durability of adhesion to tooth tissue: methods and results. J Dent Res. 2005 Feb;84:118-32.

25. Hashimoto M, Ohno H, Sano H, Tay FR, Kaga M, Kudou Y. Micromorphological changes in resin-dentin bonds after 1 year of water storage. J Biomed Mater Res. 2002;63:306-311.

26. Collares K, Opdam NJM, Laske M, Bronkhorst EM, Demarco FF, Correa MB, et al. Longevity of Anterior Composite Restorations in a General Dental Practice-Based Network. J Dent Res. 2017 Sep;96:10921099.

27. Mahn E, Rousson V, Heintze S. Meta-analysis of the influence of bonding parameters on the clinical outcome of tooth-colored cervical restorations. J Adhes Dent. 2015 Aug;17:391-403.

28. Huang X, Li L, Huang C, Du X. Effect of ethanol-wet bonding with hydrophobic adhesive on caries-effected dentine. Eur J Oral Sci 2011; 119:310-315.

29. Al-Samhan A, Al-Enezi H, Alomari Q. Clinical evaluation of posterior resin composite restorations placed by dental students of Kuwait University. Med Princ Pract 2010;19:299-304.

30. Casagrande L, Seminario AT, Correa MB, Werle SB, Maltz M, Demarco FF, et al. Longevity and associated risk factors in adhesive restorations of young permanent teeth after complete and selective caries removal: a retrospective study. Clin Oral Investig. 2017 Apr;21:847-855.

31. Barthel CR, Rosenkranz B, Leuenberg A, Roulet JF. Pulp capping of carious exposures: treatment outcome after 5 and 10 years: a retrospective study. J Endod 2000; 26:525-528.
32. Mert Z-Fairhurst EJ, Curtis JW Jr, Ergle JW, Rueggeberg FA, Adair SM. Ultraconservative and cariostatic sealed restorations:results at year 10. J Am Dent Assos. 1998;129:55-66.

33. Bauer J, Vasilache I, Schlegel AK, Wichmann M, Eitner S. Esthetics and psyche-part 1: assessment of the influence of patients' perceptions of body image and body experience on selection of existing natural tooth color. Int J Prosthodont. 2012 Jan-Feb;25:36-43.

34. Rubinstein S, Nidetz A. The art and science of the direct posterior restoration: recreating form, color and translucency. Alpha Orregan 2007; 100: 30-35.

35. Ilie N, Hickel R, Valceanu AS, Huth KC. Fracture toughness of dental restorative materials. Clin Oral Investig. 2012 Apr;16:489-98.

36. Sripetchdanond J, Leevailoi C. Wear of human enamel opposing monolithic zirconia, glass ceramic and composite resin: an in vitro study. J Prosthet Dent 2014; 112: 1141-1150.

37. Belli R, Geinzer E, Muschweck A, Petschelt A, Lohbauer U. Mechanical fatigue degradation of ceramics versus resin composites for dental restorations. Dent Mater. 2014 Apr;30:424-32.

38. Tagtekin DA, Yanikoglu FC, Bozkurt FO, Kologlu B, Sur H. Selected characteristics of an Ormocer and a conventional hybrid resin composite. Dent Mater. 2004 Jun;20:487-97.

39. Chan KHS, Mai Y, Kim H, Tong KCT, Ng D, Hsiao JCM. Review: Resin composite filling. Materials (Basel). 2010 Feb 19;3:1228-43.

40. Weinmann W, Thalacker C, Guggenberger R. Siloranes in dental composites. Dent Mater. 2005 Jan;21:68-74.

41. Beun S, Glorieux T, Devaux J, Vreven J, Leloup G. Characterization of nanofilled compared to universal and microfilled composites. Dent Mater 2007;23:51-9.

42. Flury S, Peutzfeldt A, Lussi A. Ifluence of increment thickness on microhardness and dentin bond strength of bulk fill resin composites. Dent Mater 2014;30:1104-1112.

43. Czasch $\mathrm{P}$, Illie N. In vitro comparison of mechanical properties and degree of cure of bulk fill composites. Clin Oral Investig 2013;17:227-235.

44. Fronza BM, Rueggeberg FA, Braga RR, Mogilevych $B$, Soares LE, Martin AA, et al. Monomer conversion, microhardness, internal marginal adaptation, and shrinkage stress of bulk-fill resin composites. Dent Mater. 2015;31:1542-51.

45. El-Safty S, Akhtar R, Silikas N, Watts D. C. Nanomechanical properties of dental resin-composites. Dent Mater 2012;28:1292-1300.

46. Miletic V, Peric D, Milosevic M, Manojiovic D, Mitrovic N. Local deformation fields and marginal integrity of sculptable bulkfill, low-shrinkage and conventional composites. Dent Mater 2016;32:1441-1451.

47. Pallesen U, van Dijken JW. A randomized controlled 30 years follow up of three conventional resin composites in Class II restorations. Dent Mater 2015 Oct;31:1232-44.

48. Manhart J, Chen H, Hamm G, Hickel R. Buonocore Memorial Lecture. Review of the clinical survival of direct and indirect restorations in posterior teeth of the permanent dentition. Oper Dent. 2004;29:481-508. 
49. Van Dijken JW, Pallesen U. A six-year prospective randomized study of a randomized study of a nano-hybrid and a conventional hybrid resin composite in class II restorations. Dent Mater 2013;29:191-198.

50. Labella R, Lambrechts P, Van Meerbeek B, Vanherle G. Polymerization shrinkage and elasticity of flowable composites and filled adhesives. Dent Mater 1999;15: 128-37.

51. Turssi CP, Ferracane JL, Vagel K. Filler features and their effects on wear and degree of conversion of particulate dental resin composites. Biomaterials 2005;26:4932-7.

52. Ölmez A, Tuna D. Polimerizasyon büzülmesine etki eden faktörler. Cumhuriyet Üniversitesi Diş Hekimliği Fakültesi Derg. 2002;5: 52-57.

53. Alomari QD, Reinhardt JW, Boyer DB. Effect of liners on cusp deflection and gap formation in composite restorations. Oper Dent. 2001; 26:406-411.

54. Aguiar FHB, Ajudarte KF, Lovadino JR. Effect of light curing modes and filling techniques on microleakage of posterior resin composite restorations. Oper Dent. 2002;27:557-562.

55. Niu Y, Ma X, Fan M, Zhu S. Effects of layering techniques on the micro-tensile bond strength to dentin in resin composite restorations. Dent Mater. 2009;25: 129-34.

56. Giachetti L, Russo D. S, Bambi C, Grandini R. A Review of Polmerization Shrinkage Stress: Current Techniques For Posterior Direct Resin Restorations. J Contemp Dent Pract. 2006;7:1-14.

57. Laiza T Poskus, Eliane Placido, Paulo E. Capel Candoso.Ifluence of placement techniques on Vickers and Knoop hardness of class II composite resin restorations. Dent Mater 2004;20:726-732.

58. Schneider LF, Cavalcante LM, Silikas N. Shrinkage stresses generated during resin composite applications: a review. J Dent Biomech 2010;2010:131630.

59. Mantri SP, Mantri SS. Management of shrinkage stresses indirect restorative light-cured composites: a review. J Esthet Restor Dent. 2013;25:305-13.

60. Douvitsas G. Effect of cavity design on gap formation in Class II composite resin restorations. J Prosthet Dent. 1991;65:475-479.

61. Dayangaç GB. Kompozit Restorasyonlar. 2. Baskı. İstanbul: Quintessence Yayıncılık Ltd. Şti. 2011. p.1166.

62. Cho B. H, Dickens SH, Bae JH, Chang CG, Son HH, Um CM. Effect of interfacial bond quality on the direction of polymerization shrinkage flow in resin composite restorations. Oper Dent. 2002; 27: 297-304.

63. Ghavamnasiri M, Moosavi H, Tahvildarnejad N. Effect of centripetal and incremental methods in class II composite resin restorations on gingival microleakage. J Contempor Dent Practo 2007;8:1-7.

64. Dickinson GL, Leinfelder KF, Mazer RB, Russell CM. Effect of surface penetrating sealant on wear rate of posterior composite restorations. J Am Dent Assoc 1980;121:251-255.

65. Gönülol N, Kalyoncuoğlu E, Ertaș E, Misilli T. Clinical evaluation of a low-shrinkage resin composite in endodontically treated premolars: 3 year follow-up. Clin Oral İnvestig. 2018;23:2323-2330.
66. Kuper NK, Opdam NJ, Bronkhorst EM, Huysmans MC. The influence of approximal restoration extension on the development of secondary caries. J Dent. 2012 Mar;40:241-7.

67. Montag R, Dietz W, Nietzsche S, Lang T, Weich K, Sigusch BW, et al. Clinical and Micromorphologic 29year Results of Posterior Composite Restorations. J Dent Res. 2018 Dec;97:1431-1437.

68. Tyas MJ. Placement and replacement of restorations by selected practitioners. Aus Dent J 2005;50:81-9.

69. Wu J, Weir MD, Zhang Q, Zhou C, Melo MAS, Xu HH. Novel self healing dental resin with microcapsules of polimerizable triethyleneglycol dimetacrylate and N,N-dihydroxyethyl-p-toluidine. Dent Mater 2016;32:294-304.

70. Althaqafi KA, Satterthwaite J, Silikas N. A review and current state of autonomic self-healing microcapsules-based dental resin composites. Dent Mater. 2020;36:329-342.

71. Opdam NJ, Bronkhorst EM, Roeters JM, Loomans BA. Longevity and reasons for failure of sandwich and total etch posterior composite resin restorations. J Adhes Dent. 2007b;9:469-475.

72. Bernardo M, Luis H, Martin MD, Leroux BG, Rue T, Leitão J, et al. Survival and reasons for failure of amalgam versus composite posterior restorations placed in a randomized clinical trial. J Am Dent Assoc. 2007 Jun;138:775-83.

73. Baroudi K, Silikas N, Watts DC. In vitro pulp chamber temperature rise from irradiation and exotherm of flowable composites. Int J Pediatr Dent. 2009;19:4854.

74. Boruziniat A, Khaki $\mathrm{H}$, Majidinia S. Retrospective evaluation of the clinical performance of direct composite restorations using the snow-plow technique: Up to 4 years follow-up. J Clin Exp Dent. 2019 Nov 1;11:964-968.

75. Tanner J, Tolvanen M, Garoushi S, Säilynoja E. Clinical evaluation of fiber-reinforced composite restorations in posterior teeth - results of 2.5 year follow-up. Open Dent J. 2018 Jun 29;12:476-485.

76. Vichi A, Ferrari M, Davidson CL. Color and opacity variations in three different resin-based composite products after water aging. Dent Mater. 2004;20:530-4.

77. Opdam NJ, van de Sande FH, Bronkhorst E, Cenci MS, Bottenberg P, Pallesen U, et al. Longevity of posterior composite restorations: a systematic review and meta-analysis. J Dent Res. 2014 Oct;93:943-9.

78. Lempel E, Lovász BV, Meszarics R, Jeges S, Tóth Á, Szalma J. Direct resin composite restorations for fractured maxillary teeth and diastema closure: A 7 years retrospective evaluation of survival and influencing factors. Dent Mater. 2017 Apr;33:467-476.

79. Koç-Vural U, Kerimova L, Baltacioglu İH, Kiremitçi A. Bond strength of dental nanocomposites repaired with a bulkfill composite. J Clin Exp Dent. 2017;9:437442.

80. Uctasli MB, Can HE, Omurlu H. Amalgam restorasyonların değiştirilme nedenleri ve klinik ömürleri. A. Ü Diş Hek. Fak. Derg 2002;29:9-16.

81. Mjör IA, Shen L, Eliasson ST, Richter S. Placement and replacement of restorations in general dental practice in Iceland. Oper Dent. 2002;27:17-123. 
82. Bogacki RE, Hunt RJ, del Aguila M, Smith WR. Survival analysis of posteriro restorations using an insurance claims database. Oper Dent. 2002;27:488-492.

83. Hannig C, Laubach S, Hahn P, Attin T. Shear bond strength of repaired adhesive filling materials using different repair procedures. J Adhes Dent. 2006;8:3540.

84. Ozcan M, Pekkan G. Effect of different adhesion strategies on bond strength of resin composite to composite-dentin complex. Oper Dent 2013;38:63-72.

85. Loomans BA, Cardoso MV, Roeters FJ, Opdam NJ, De Munck J, Huysmans MC, et al. Is there one optimal repair technique for all composites? Dent Mater. 2011 Jul;27:701-9.

86. Hemadri M, Saritha G, Rajasekhar V, Pachlag KA, Purushotham R, Reddy VK. Shear bond strength of repaired composites using surface treatments and repair materials: an in vitro study. J Int Oral Health 2014;6:22-5.

87. Yokokawa M, Rikuta A, Tsujimoto A, Tsuchiya K, Shibasaki S, Matsuyoshi S, et al. Influence of methyl mercaptan on the repair bond strength of composites fabricated using self-etch adhesives. Eur J Oral Sci. 2015 Feb;123:46-52.

88. Yesilyurt C, Kusgoz A, Bayram M, Ulker M. Initial repair bond strength of a nano-filled hybrid resin: effect of surface treatments and bonding agents. J Esthet Restor Dent. 2009;21:251-60.

89. Gutierrez NC, Moecke SE, Caneppele TM, Perote LC, Batista GR, Huhtalla MF, et al. Bond Strength of Composite Resin Restoration Repair: Influence of Silane and Adhesive Systems. J Contemp Dent Pract. 2019 Aug 1;20:880-886.

90. Mondelli J, Steagall L, Ishikiriama A, de Lima Navarro MF, Soares FB. Fracture strength of human teeth with cavity preparations. J Prosthet Dent. 1980 Apr;43:419-22.

91. Baldissera RA, Corrêa MB, Schuch HS, Collares K, Nascimento GG, Jardim PS, et al. Are there universal restorative composites for anterior and posterior teeth? J Dent. 2013 Nov;41:1027-35.

92. Borgia E, Baron R, Borgia JL. Quality and survival of direct light-activated composite resin restorations in posterior teeth: a 5- to 20-Year retrospective longitudinal study. J Prosthodont. 2019 Jan;28:195-203.

93. Ali H, Abdin MJ, Akhter NJ, Hossain M. Nanohybrid and microfilled composite resin in class II restoration of permanent molar teeth. Bangabandhu Sheikh Mujib Med Univ J. 2019;12:94-98.

94. Ferracane JL. Buonocore Lecture. Placing dental composites--a stressful experience. Oper Dent. 2008 MayJun;33:247-57.

95. Cheng L, Weir MD, Xu HH, Antonucci JM, Kraigsley AM, Lin NJ, et al. Antibacterial amorphous calcium phosphate nanocomposites with a quaternary ammonium dimethacrylate and silver nanoparticles. Dent Mater. 2012 May;28:561-72.

96. Handa K, Murakami N, Yamazaki T, Takahashi H, Wakabayashi N. The ball-on-disk cyclic wear of CAD/ CAM machinable dental composite and ceramic materials. J Oral Sci 2017;59:589-96.

97. Tabassum ST, Hossain M, Gafur MA, Ali H, Abdin MJ, Moral MAA. Wear of nanohybrid and microfilled composite resin in occlusal restoration of first permanent molar tooth. Bengabandhu Sheikh Mujib Med Univ J. 2019;12:133-137.

98. Cetin AR, Unlu N, Cobanoglu N. A five-year clinical evaluation of direct nanofilled and indirect composite resin restorations in posterior teeth. Op Dent 2013;38:31-41.

99. Ozakar-Ilday N, Zorba YO, Yildiz M, Erdem V, Seven N, Demirbuga S. Three year clinical performance of two indirect composite inlays compared to direct composite restorations. Med Oral Patol Oral Cir Bucal. 2013;18:521-528.

100. Huth KC, Chen HY, Mehl A, Hickel R, Manhart J. Clinical study of indirect composite resin inlays in posterior stress-bearing cavities placed by dental students:result after 4 years. J Dent 2011;39:478-88.

101. Leinfelder KF. Indirek posterior composite resins. Compend Contin Educ Dent 2005;26:495-503.

102.İlday, A , Urvasızoğlu, A , Seven, P . İndirekt kompozit inley restorasyonlar ile direkt kompozit restorasyonların mikrosızıntı yönünden karşılaștırılması. Atatürk Üniversitesi Diș Hekimliği Fakültesi Derg. 2009 (2009): 76-84.

103. Dejak B, Mlotkowski A. A comparison of stresses in molar teeth restored with inlays and direct restorations, including polymerization shrinkage of composite resin and tooth loading during mastication. Dent Mater 2015;31:77-87.

104.Van Dijken JW. Direct resin composite inlays/onlays: an 11-year follow-up. J Dent 2000;28:299-306.

105. Bresser RA, Gerdolle D, van den Heijkant IA, Sluiter-Pouwels LMA, Cune MS, Gresnigt MMM. Up to 12 years clinical evaluation of 197 partial indirect restorations with deep margin elevation in the posterior region. J Dent. 2019 Dec;91:103227.

106. Torres CRG, Mailart MC, Crastechini É, Feitosa FA, Esteves SRM, Di Nicoló R, et al. A randomized clinical trial of class II composite restorations using direct and semidirect techniques. Clin Oral Investig. 2020 Feb;24:1053-1063.

107.Zaimoglu A, Can G. Sabit Protezler. Ankara: Ankara Üniversitesi Basımevi;2004. P. 165-80.

108. da Veiga AM, Cunha AC, Ferreira DM, da Silva Fidalgo TK, Chianca TK, Reis KR, et al. Longevity of direct and indirect resin composite restorations in permanent posterior teeth: A systematic review and meta-analysis. J Dent. 2016 Nov;54:1-12.

109. Miyazaki T, Hotta Y, Kunii J, Kuriyama S, Tamaki Y. A review of dental CAD/CAM: current status and future perspectives from 20 years of experience. Dent Mater J. 2009 Jan;28:44-56.

110. Kawaguchi-Uemura A, Mine A, Matsumoto M, Tajiri Y, Higashi M, Kabetani T, et al. Adhesion procedure for CAD/CAM resin crown bonding: Reduction of bond strengths due to artificial saliva contamination. J Prosthodont Res. 2018 Apr;62:177-183.

111. Shembish FA, Tong H, Kaizer M, Janal MN, Thompson VP, Opdam NJ, et al. Fatigue resistance of CAD/CAM resin composite molar crowns. Dent Mater. 2016 Apr;32:499-509.

112. Johnson AC, Versius A, Tantbirojn D, Ahuja S. Fracture strength of CAD/CAM composite and composite-ceramic occlusal veneers. J Prosthodont Res 2014;58:10714. 
113. Berg JH, Croll TP. Glass ionomer restorative cement systems: an update. Pediatr Dent. 2015;37:116-124.

114. Loguercio AD, Reis A. Application of a dental adhesive using the self-etch and etch-and-rinse approaches: an 18-month clinical evaluation. J Am Dent Assoc 2008;139:53-61.

115. Boing TF, de Geus JL, Wambier LM, Loguercio AD, Reis A, Gomes OMM. Are glass-ionomer cement restorations in cervical lesions more long-lasting than resin-based composite resins? A systematic review and meta-analysis. J Adhes Dent. 2018;20:435-452.

116. Szesz A, Parreiras S, Reis A, Loguercio A. Selective enamel etching in cervical lesions for self-etch adhesives: A systematic review and meta-analysis. J Dent. 2016 Oct;53:1-11.

117. Ikemura K, Tay FR, Endo T, Pashley DH. A review of chemical-approach and ultramorphological studies on the development of flüoride-releasing dental adhesives comprising new pre-reacted glass ionomer(PRG) fillers. Dent Mater J. 2008;27:315-39.

118. Gonulol N, Ozer S, Sen Tunc E. Water sorption, solubility, and color stability of giomer restoratives. J Esthet Restor Dent 2015;27:300-6.

119. Geukins S, Goossens A. Occupational contact allergy to (meth)arcylates. Contact Dermatitis 2001;44:1539.

120. Menne-Happ U, Ilie N. Effect of gloss and heat on the mechanical behaviour of a glass carbomer cement. J Dent. 2013 Mar;41:223-30.

121. Orözü Öİ, Karadağlıŏlu B, Ulusoy N. Güncel restoratif materyallerin oral biyofilme etkileri. Türkiye Klinikleri J Dental Sci 2017; 23: 130-8.

122. Sud N, Gupta AK, Sharma V, Minocha A. Comperative evaluation of the fracture resistance of maxillary premolars with mesio-occluso distal cavities restored with zirconomer, amalgam, composite and GIC: An in vitro study. Int J Res Health Allied Sci 2019;5:79-82.

123. Friedl K, Hiller KA, Friedl KH. Clinical performance of a new glass ionomer based restoration system: a retrospective cohort study. Dent Mater 2011;27:10311037.

124. Celik EU, Tunac AT, Yllmaz F. A randomized, controlled, split-mouth trial evaluating the clinical performance of high-viscosity glass ionomer restorations in noncarious cervical lesions: two year results. J Adhes Dent 2018; 20:299-305.

125. Bagheri R, Plamara J, Mese A, Manton DJ. Effect of a self adhesive coating on the load-bearing capacity of tooth-colored restorative materials. Aust Dent J 2017;62:71-78.

126. Tal E, Kupietzky A, Fuks AB, Tickotsky N, Moskovitz M. Clinical performance of heat-cured high-viscosity glass ionomer class II restorations in primary molars: a preliminary study. J Clin Pediatr Dent 2017;41:264270.

127. Scholtanus JD, Huysmans MC. Clinical failure of class II restorations of a highly viscous glass-ionomer material over a 6 year period: a retrospective study. J Dent 2007;35:156-162.

128. Diem VT, Tyas MJ, Ngo HC, Phuong LH, Khanh ND. The effect of a nano-filled resin coating on the 3 year clinical performance of a conventional high-viscosity glass-ionomer cement. Clin Oral Investig 2014;18:753-59.
129. H Balkaya, S Arslan. A two-year clinical comparison of three different restorative materials in class II cavities. Op Dent 2020;45:32-42.

130.Pameijer CH, Garcia-Godoy F, Morrow BR, Jefferies SR. Flexural strangth and flexural fatigue properties of resin-modified glass ionomers. J Clin Dent 2015;26:23-7.

131. Pinto Gdos S, Oliveira LJ, Romano AR, Schardosim LR, Bonow ML, Pacce M, et al. Longevity of posterior restorations in primary teeth: results from a paediatric dental clinic. J Dent. 2014 Oct;42:1248-54.

132. Pousette Lundgren G, Dahllöf G. Outcome of restorative treatment in young patients with amelogenesis imperfecta. a cross-sectional, retrospective study. J Dent. 2014 Nov;42:1382-9.

133. Braga RR, Ballester RY, Ferracane JL. Factors involved in the development of polymerization shrinkage stress in resin composites: A systematic review. Dent Mater 2005;21:962-70.

134.ADA Counilon Scientific Affairs. Direct and indirect restorative materials. J Am Dent Assoc. $2003 ; 134: 463-472$.

135. Lambrechts P, Goovaerts K, Bharadwaj D, Munck J, Bergmans L, Peumans M, et al. Degradation of tooth structure and restorative materials: A review. Wear. 2006;261:980-986.

136. Opdam NJM, Bronkhorst EM, Roeters JM, Loomans BAC. A retrospective clinical study on longevity of posterior composite and amalgam restorations. Dent Mater 2007;23:2-8.

137. Kovarik RE. Restoration of posterior teeth in clinical practice: evidence base for choosing amalgam versus composite. Dent. Clin. N. Am. 2009;53:71-76.

138. Soares AC, Cavalheiro A. A review of amalgam and composite longevity of posterior restorations. Reu Port Estomatol Med Dent Cir Maxilofac 2010;51:155164.

139. Moraschini V, Fai CK, Alto RM, Dos Santos GO. Amalgam and resin composite longevity of posterior restorations: A systematic review and meta-analysis. J Dent. 2015 Sep;43:1043-1050.

140.Opdam NJ, Bronkhorst EM, Loomans BA, Huysmans MC. 12-year survival of composite vs. amalgam restorations. J Dent Res. 2010 0ct;89:1063-7.

141. Soares PV, Santos-Filho PC, Gomide HA, Araujo CA, Martins LR, Soares CJ. Influence of restorative technique on the biomechanical behaviour of endodontically treated maxillary premolars. Part II: strain measurement and stress distribution. J Prosthet Dent 2008;99:114-22.

142. Mackert JR Jr, Wahl MJ. Are there acceptable alternatives to amalgam? J Calif Dent Assoc. 2004;32:601-10. 